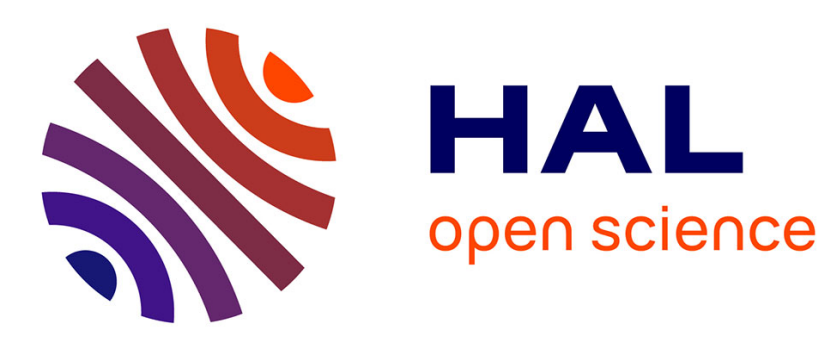

\title{
Finance-Growth Nexus and Dual-Banking Systems: Relative Importance of Islamic Banks
}

Pejman Abedifar, Iftekhar Hasan, Amine Tarazi

\section{To cite this version:}

Pejman Abedifar, Iftekhar Hasan, Amine Tarazi. Finance-Growth Nexus and Dual-Banking Systems:

Relative Importance of Islamic Banks. 2016. hal-01296613

\section{HAL Id: hal-01296613 \\ https://hal-unilim.archives-ouvertes.fr/hal-01296613}

Preprint submitted on 1 Apr 2016

HAL is a multi-disciplinary open access archive for the deposit and dissemination of scientific research documents, whether they are published or not. The documents may come from teaching and research institutions in France or abroad, or from public or private research centers.
L'archive ouverte pluridisciplinaire HAL, est destinée au dépôt et à la diffusion de documents scientifiques de niveau recherche, publiés ou non, émanant des établissements d'enseignement et de recherche français ou étrangers, des laboratoires publics ou privés. 


\title{
Finance-Growth Nexus and Dual-Banking Systems: Relative Importance of Islamic Banks
}

\author{
Pejman Abedifar $^{\mathrm{a}}$, Iftekhar Hasan ${ }^{\mathrm{b}, \mathrm{c}}$, Amine Tarazi $^{\mathrm{d}}$ \\ ${ }^{a}$ Centre for Responsible Banking \& Finance, School of Management, University of St. Andrews, Scotland, U.K. \\ ${ }^{b}$ Fordham University, 5 Columbus Circle, 11th Floor, New York, NY 10019 \\ ${ }^{c}$ Bank of Finland, FI 00101, Helsinki, Finland \\ ${ }^{d}$ Université de Limoges, LAPE, 5 rue Félix Eboué, 87031 Limoges, France
}

\begin{abstract}
This paper investigates the relative importance of Islamic banks, alongside their conventional counterparts, in relation tobanking and financial development and economic welfare. Using a sample of 22 Muslim countries, with dual-banking systems, during the period 1999-2011, this paper reports some significant positive relationship between the market share of Islamic banks and the development of financial intermediation, financial deepening and economic welfare, particularly in low income or predominantly Muslim countries,and countries with a comparatively higher uncertainty avoidance index. Additionally, the results reveal thata greater market share of Islamic banks is associated with higherefficiency of conventional banks.
\end{abstract}

\section{JELClassifications:G21, O16}

Keywords: Banking System Structure, Financial Development, Finance-Growth Nexus, Islamic Banking.

Send all correspondence to Iftekhar Hasan, ihasan@fordham.edu, Tel: + 15188926532.

E-mail addresses of authors: pa31@st-andrews.ac.uk, ihasan@ fordham.edu, amine.tarazi@unilim.fr.

Acknowledgement:Thanks to Kose John, Philip Molyneux, and Alain Sauviat and delegates at the ERF $20^{\text {th }}$ Annual Conference, Cairo,the $4^{\text {th }}$ Islamic Banking conference, Lancaster University, the International Islamic Banking and FinanceConference, Riyadh, March 2016, for constructive comments on earlier versions of the paper. All errors, of course, rest with the authors. 


\section{Introduction}

Financial systems mitigate information and transaction costs. The core functions of financial markets and institutions are to facilitate savings mobilization, informationacquisition and processing, theefficient allocation of funds and to encourage effectivecorporate governance (Levine, 1997). Awell-functioning financial market and efficient financial intermediation can spur capital productivity and foster economic growth (Rousseau and Sylla, 1999; Beck, et al., 2000 and Christopoulos and Tsionas, 2004; Levine, 2005 among others).

The extant literature discusses the importance of how differently shaped financial systems can affect economic development (e.g. Levine et al., 2000; Beck and Levine, 2004; Merton and Bodie, 2004 and Berger et al., 2004). Differences in banking industry structures can also differently impact the economy as a whole. For instance, Berger et al. (2004) study the role of community banks in the economic growth of 49 countries between 1993 and 2000 . Their findings suggest that where small, private, domestically-owned banks have larger market shares and higher efficiency,this can boost economic growth. In this paper we study whether the coexistence of Islamic and conventional banking contributes to financial development and economic welfare.

According to The Banker (2013), Islamic finance is growing at the rate of $15 \%$ to $20 \%$ per annum. Globally, Islamic banking assets in commercial banks are set to exceed $\$ 1.7$ trillion in 2013 (Ernst \& Young, 2013-2014).

The empirical work in this area has grown accordingly. The extant literature analyzes various features of Islamic banking and finance: investment financing (Aggarwal and Yousef, 2000), securitization (Jobst, 2007), mortgage loans (Ebrahim, 2009), stability (Čihák and Hesse, 2010), relationship banking (Ongena and Şendeniz-Yüncü, 2011), business models (Beck et al., 2013), risk (Abedifar, et al., 2013), efficiency (Johnes et al., 2014; Saeed and 
Izzeldin, 2014), loan default rates (Baele et al., 2014), mutual funds (Abdelsalam et al., 2014) and valuation (Elnahass, et al., 2014) ${ }^{1}$.

However, there are few studies on the role and relative importance of Islamic banking in the transformation of the banking and finance sectors of respective countries. Using a sample of 20 Muslim countries for the 2000-2005 period, Gheeraert (2014) shows that development of Islamic banking sector boosts the whole banking system. Gheeraert and Weill (2014) claim that the development of Islamic banking improves macroeconomic efficiency. Islamic banking has changed the financial structure of many countries by introducing a dual financial system in which both Islamic and conventional institutions operate. This paper attempts to fill the void by investigating the characteristics of Islamic banking from the finance-growth perspective.

Islamic banks offer financial products and services that are compatible with Islamic doctrine,which allows Muslim individuals and firms with religious concerns to have access to finance or move from an informal to a formal financial system. In short, Islamic banks can mitigate financial exclusion and bring financial services to a wider population. This can also promote better strategiesfor poverty alleviation (Rajan, 2006).

Changes in market structure may affect banks' performance. In a dual-banking system, Islamic and conventional banks do not merely play a supplementary role to one another, they compete with each other for clients and investors. Whether and how conventional banks are affected by the presence of Islamic banks is an important issue from the policy-making perspective and we examine how the efficiency of conventional banks is affected when they operate alongside Islamic banks.

We focus on commercial banking industries in 22 Muslim countries with dualbanking systems during the 1999-2011 period. Overall, we find that the effect of a dual-

\footnotetext{
${ }^{1}$ For a review of the literature, please refer to Abedifar et al. (2015).
} 
banking system (where Islamic banks operate alongside their conventional counterparts) on financial development, economic growth and poverty alleviation depends on the institutional environment.Thisis examined in our study from three perspectives: religion, wealth and culture. Our results show that a higher market share of medium-size Islamic banks is associated with: greater funding mobilization and credit allocation, economic growth and poverty alleviation in countries with relatively greater proportions of Muslims in their populations; countries with a comparatively higher uncertainty avoidance index; and countries with lower GDP per capita. Our bank-level analyses reveal a positive relationship between the presence of large Islamic banks and the efficiency of conventional banks in predominantly Muslim countries.In more religiously diverse Muslim countries, the efficiency of conventional banks is positively linked to the market share of conventional banks with Islamic window/branches.

The remainder of the paper is organized as follows. Section 2 presents the research motivation and econometric specifications, section 3 describes our sample of observations, and section 4 discusses the results. Finally, section 5 concludes.

\section{Research Motivation and Econometric Specifications}

\subsection{FINANCIAL INTERMEDIATION AND ECONOMIC WELFARE}

We study the relationship between the coexistence of Islamic banks and conventional banks and national financial development in terms of savings mobilization and funds allocation. We also explore the link between the presence of Islamic banks and economic growth, income inequality, and poverty alleviation. 


\subsubsection{FINANCIAL INTERMEDIATION}

Many Muslims do not use traditional financial products and services, because they believe these conflict with their religious beliefs. They may use financial services provided by the informal market. ${ }^{2}$ A number of surveys highlight that Muslims prefer Sharia-compliant financial products and services. In Algeria, for instance, a study shows that around $20.7 \%$ of micro-enterprise owners do not apply for loans primarily due to religious concerns (Frankfurt School of Finance and Management, 2006). In Indonesia, around 49\% of the rural population of East Java prefers Islamic finance and believes that interest is prohibited (C.G.A.P., 2008). Honohan (2008) finds that in member countries of the Islamic Development Bank (i.e., all $\mathrm{OIC}^{3}$-member countries except Guyana) only 28 percent of the total adult population uses formal or semi-formal financial products and services for deposit and borrowing activities.

Given the relatively low access to financial institutions and products in most Muslim countries (e.g. Honohan, 2008), there is considerable potential for Islamic finance, by moving lenders and borrowers from the informal to formal markets. ${ }^{4}$ Hence, Islamic banks are expected to play a complementary role to conventional banks in intermediating financial resources.Islamic and conventional banking may also substitute for each other; for example, Islamic banks can absorb lenders and borrowers from conventional financial institutions. We therefore explore whether the presence of Islamic banks can increasefinancial intermediation. First, we investigate how the deposits in the banking industry and financial system are affected by the presence of Islamic banks.We then examine the relationship between the volume of private credit and the market share of Islamic banks.

\footnotetext{
${ }^{2}$ Often known as the curb market.

${ }^{3}$ Organization of Islamic Conference; please refer to http://www.oic-oci.org/oicv2/home/?lan=en

${ }^{4}$ Some economists believe that curb markets are more efficient in savings and investment intermediation (van Wijnbergen, 1983; Taylor, 1983; Buffie, 1984); however, Fry (1988) argues that informal markets are not necessarily as efficient as formal markets. Chandavarkar (1992) claims that curb markets are unorganized and do not play a substantial role in financial-resource intermediation to boost economic growth. The main problem for examining the potential contribution of informal markets to economic growth is the lack of data.
} 


\subsubsection{Economic Growth}

Whether the presence of Islamic banks can affect economic growth is an empirical question that we attempt to address in this study. Existing studies show that religious individuals are more risk-averse than other agents (Miller and Hoffmann, 1995; Osoba, 2003; Hilary and Hui, 2009). Similarly, Islamic financial institutions might be more risk-averse than their conventional counterparts. Therefore, they might limit entrepreneurship by encouraging borrowers to select low-risk projects or to invest excessively in tangible assets. Furthermore, Islamic financiers may prefer to allocate funds to the real economy, becausethey are not authorized to allocate financial resources to speculative activities.

\subsubsection{INCOME INEQUALITY and POVERTY ALLEVIATION}

A profit-maximization strategy encourages financial institutions to establish branches and networks in large cities or capital-oriented areas rather than in areas with low population density or low income. This may leave the poor withrelatively limited access to financial products and services such as deposits and loans. Additionally, some poor Muslims may prefer to bank with Sharia-compliant financial institutions. The lack of access to finance can exacerbate poverty (Ayyagari et al, 2008). The limited access of the poor to finance is addressed by the microfinance literature (see Armendariz de Aghion and Morduch, 2005 among others), where governments might be encouraged to promote financial services in rural and low income areas. The government of India, for instance, adopted a policy, during the period 1977-1990, to support the opening bank branches in areas without any bank $^{5}$.Thatpolicy has been associated with a $60 \%$ reduction in rural poverty (Burgess and Pande, 2005).

\footnotetext{
${ }^{5}$ The government allowed establishment of a new branch in districts that had already benefited from bank presence provided that the bank opened four branches in areas without bank presence.
} 
Rajan (2006) argues that it is better to focus on finance for all rather than to focus exclusively on the poor. This is more practical from the political economy perspective ${ }^{6}$ and a number of empirical studies show that the poor also benefits from a more generalpolicy. Honohan (2004) finds a negative relationship between financial development and headcount ratio. Beck et al. (2007) claim that financial deepening not only has a positive effect on economic growth, but it also mitigates income inequality and reduces poverty.

Islam, like other Abrahamic religions (Judaism and Christianity), encourages lending that it is free of interest. The motivation for the prohibition of interest is to prevent the oppression of the poor. Hence, the availability of Islamic finance may lessen income inequality and alleviate poverty, given thatIslamic financial institutions may incorporate poverty alleviation in their business strategies. They are expected to have a greater incentive to offer financial products and services to poor clients. We therefore expect to find that Islamic financiers contribute more to social and development activities than their conventional counterparts.

Alternatively, Islamic financial institutions may offer Sharia-compliant financial products and services as part of a marketing strategy to attract clients that are highly religious. They might also follow a profit-maximization approach similar to conventional financial institutions ${ }^{7}$, so that there would be few differences between Islamic and conventional products. Hence, Islamic financial institutions may not be more effective in reducing poverty than conventional financial institutions, so it is important to investigate the impact of Islamic financial institutions on income inequality and poverty.

\footnotetext{
${ }^{6}$ For instance, microfinance is well practiced only in a few countries such as Bangladesh, Indonesia and Thailand (Honohan, 2004).

${ }^{7}$ We follow existing literature (see e.g. Aggarwal and Yousef, 2000 Chong and Liu, 2009; Beck et al, 2013 and Abedifar et al, 2013) and assume that Islamic commercial banks follow a profit maximization strategy similar to conventional commercial banks within the constraints imposed by Sharia, e.g. prohibition of interest-based financial activities.
} 


\subsubsection{ECONOMETRIC SPECIFICATIONS}

We adopt the following panel specification for our analyses. To control for individual unobservable heterogeneity across countries, we use the fixed-effect technique in our estimation and cluster standard errors at the country level.

$$
\begin{aligned}
& \mathrm{Y}_{\mathrm{j}, \mathrm{t}}=\alpha_{0}+\alpha_{11} \times \text { Small_ISB_Share }_{\mathrm{j}, \mathrm{t}}+\alpha_{12} \times \text { Medium_ISB_Share }_{\mathrm{j}, \mathrm{t}}+\alpha_{13} \times \text { Large_ISB_Share }_{\mathrm{j}, \mathrm{t}}+ \\
& \alpha_{21} \times \text { Small_ISW_Share } e_{j, t}+\alpha_{22} \times \text { Medium_ISW_Share }_{j, t}+\alpha_{23} \times \text { Large_ISW_Share }_{j, t}+ \\
& \alpha_{3} \times \text { Foreign_Banks_Share }_{\mathrm{j}, \mathrm{t}}+\alpha_{4} \times \text { State_Banks_Share }_{\mathrm{j}, \mathrm{t}}+ \\
& \alpha_{5} \times \text { Inflation }_{\mathrm{j}, \mathrm{t}}+\alpha_{6} \times \text { Per_Capita }_{\mathrm{j}, \mathrm{t}}+\alpha_{7} \times \text { Remittance_Inflow }_{\mathrm{j}, \mathrm{t}}+\alpha_{8} \times \text { Trend }_{\mathrm{t}}+\varepsilon_{\mathrm{j}, \mathrm{t}}
\end{aligned}
$$

Where $j$ subscript denotes individual countries and $t$ denotes the time dimension.

$Y_{j, t}$ is our dependent variable. We use the following three proxies for our financialintermediation study: total deposits of commercial banks to gross domestic product (GDP) ratio (Bank Deposit); total deposits in the financial system to GDP ratio (Financial System Deposit) representing the volume of deposits mobilization; and the ratio of private credit to GDP (Private Credit) as a proxy for credit allocation.

For our economic growth analysis, we employ the annual growth rate of GDP per capita, calculated using the purchasing power parity $(P P P)$ method (Economic Growth) as the dependent variable $\left(Y_{j, t}\right)$.

We explore income inequality and poverty alleviation using five proxies: the Gini index (Gini); the share of people with less than $\$ 1.25$ a day based on PPP in the total population (Poverty Ratio International); the percentage of people below the national poverty line (Poverty Ratio National); the intensity of poverty by the percentage who live on less than $\$ 1.25$ a day (Poverty Gap International); and the percentage of people who live below the rural poverty line (Poverty Ratio Rural).

$I S B$ Shareis our variable of interest andrepresents the assets of commercial Islamic banks as a percentage of the total assets of the whole commercial banking industry. Islamic banking can enter the financial system in two ways: The establishment of pure Islamic banks 
or by launching Islamic branches/window in conventional banks. The first way increases both the size of the financial sector and the number of financial institutions, yielding higher market competition.The second way increases the size of the financial system with no increase in the number of participants, resulting in higher market power. Following Beck et al. (2013), we split Islamic banks into three categories: Small, Medium and Large. We define Small banksas those with total assets below $\$ 100$ million. Medium banks are thosewith total assets above $\$ 100$ million and below $\$ 1$ billion. Large banks are thosewith total assets above \$1 billion.

We are interested in the role of pure Islamic banks in financial systems and the economy. We control for the Islamic branches/windowby including the share of Small, Medium and Large Islamic window banks (ISW Share) in the total assets of the commercial banking sector. The benchmark is then the share of pure commercial conventional banks in the total assets of the banking system.

We try to capture the heterogeneities associated with the structure of the banking sector in terms of ownership, using the share of total assets of foreign and state-owned banks in total assets (Foreign Bank Share and State Bank Share). The benchmark is the share of domestic private banks in total assets.

We use fixedeffects technique for our estimation,whichaccounts for unobservable factors.We control for a number of macroeconomic and institutional environment factors such as inflation, remittance inflow, GDP per capita, culture and religion. Inflation is represented in our model by the annual growth rate of the GDP deflator (Inflation);it affects financial development and economic welfare (Rousseau and Wachtel, 2002). We also consider remittance inflowas a percentage of GDP (Remittance Inflow) in our model. Overseas remittance and capital inflow has been increased over time and may influence our variables of interest. Heterogeneity across countries due to differences in incomeis captured by introducing GDP per capital measured by the PPP approach (Per Capita) into our model. 
Moreover, we split our sample into two groups on the basis of the median value of Per Capita to explore the impact of Islamic banking presence in relatively poor countries.

Religion is represented by the proportion of Muslims in the population (Muslim Share).This follows Abedifar et al. (2013), who find significant variations in the performance of Islamic banks across countries. We expect the presence of Islamic banks to be influential particularly in predominantly Muslim countries. We also expect that the introduction of Islamic banks can attract more people to the formal financial sector and more effectively contribute to financial deepening in Muslim countries with relatively a higher uncertainty avoidance index (Uncertainty Avoidance) issued by Hofstede (2001). Since religion and culture are largely time-invariant, we cannot directly use them in our model. We split our sample into two parts based on the median value of Muslim Share and Uncertainty Avoidance.From that basis, we explore how the market share of Islamic banks is linked to financial development and economic welfare in countries. ${ }^{8}$ Finally, we add a trend variable. Table A1 in the appendix describes the variables of interest, the control variables, and the dependent variable.

\subsection{EFFICIENCY OF CONVENTIONAL BANKS}

How the presence of Islamic banks may affect the efficiency of conventional banks is an interesting question which we attempt to address in this paper.

Conventional banks might operate more efficiently in a dual-banking system due to competitive pressure. The pressure might be stronger for conventional banks than Islamic banks, because of the preference of Muslims with religious concerns for Islamic financial institutions. The efficiency of conventional banks might improve with the greater competition that is implied by a rise in the market share of Islamic banks. Furthermore, Islamic banks

\footnotetext{
${ }^{8}$ We are thankful to anonymous referees for their fruitful comments on our modelling.
} 
might be inherently less efficient in offering complicated Sharia-compliant financial products ${ }^{9}$. Taken together, it is unclear whether a higher market share of Islamic banks can significantly alterthe efficiency of conventional banks.

To investigate the link between the market share of Islamic banks and the efficiency of conventional banks, we estimate the following panel specification using the fixed-effect technique with standard errors clustered at the bank level. The technique accounts for individual, unobservable heterogeneity across banks.

$\begin{aligned} \text { Inefficiency }_{\mathrm{i}, \mathrm{t}}= & \beta_{0}+\beta_{11} \times \text { Small_ISB_Share }_{\mathrm{j}, \mathrm{t}}+\beta_{12} \times \text { Medium_ISB_Share }_{\mathrm{j}, \mathrm{t}}+\beta_{13} \times \text { Large_ISB_Share }_{\mathrm{j}, \mathrm{t}}+ \\ & \beta_{21} \times \text { Small_ISW_Share }_{\mathrm{j}, \mathrm{t}}+\beta_{22} \times \text { Medium_ISW_Share }_{\mathrm{j}, \mathrm{t}}+\beta_{23} \times \text { Large_ISW_Share }_{\mathrm{j}, \mathrm{t}}+ \\ & \beta_{3} \times \mathrm{HHI}_{\mathrm{j}, \mathrm{t}}+\beta_{4} \times \mathrm{PDomestic}_{2} \text { Doterest_Rate }_{\mathrm{j}, \mathrm{t}}+\beta_{5} \times \text { Per_Capita }_{\mathrm{j}, \mathrm{t}}+ \\ & \beta_{6} \times \text { Per_Capita_Growth }_{\mathrm{j}, \mathrm{t}}+\beta_{7} \times \text { Capital }_{\mathrm{i}, \mathrm{t}}+\beta_{8} \times \text { Size }_{\mathrm{i}, \mathrm{t}}+\beta_{9} \times \text { Credit Risk }_{\mathrm{i}, \mathrm{t}}+ \\ & \sum_{y=1}^{12} \beta_{10, \mathrm{y}} \times \text { Year_Dummies }_{\mathrm{t}, \mathrm{y}}+\xi_{\mathrm{i}, \mathrm{t}}\end{aligned}$

where the $i, t$ and $j$ subscripts denote individual banks, time dimension, and countries, respectively. Small, Mediumand Large ISB Share is our variable of interest, and we study its impact on Inefficiency of conventional banks operating in a dual-banking system.

Inefficiency(our dependent variable) is represented by the ratio of total noninterest expense to total operating income. We control for macroeconomic factors such as market concentration together with bank-level controls. Because the Hausman test suggests the use of the fixed-effect technique, we do not include ownership dummies in our model. Besides controlling for the market share of Small, Mediumand LargeISW Share, we introduce four country-level variables to capture cross-country variations. We control for the impact of banking-sector concentration by adding the Herfindahl-Hirschman Index $(H H I)$ to our model. The relationship between market concentration and efficiency is not clear ex ante. On the one hand, in more concentrated markets, banks have less incentive to increase their efficiency (Quite Life Hypothesis proposed by Hicks, 1935).On the other hand, more efficient banks

\footnotetext{
${ }^{9}$ Some studies show that Islamic financial products are more expensive than conventional ones (e.g. Baele et al, 2014). This could be because of higher inefficiency of Islamic banks or extra rents that Islamic banks extract from their clients for offering Sharia-compliant financial products.
} 
gain larger market shares that may lead to greatermarket concentration (Efficient-Structure Hypothesis proposed by Demsetz, 1973).

We take into account the level of domestic interest rates (Domestic Interest Rate). The extant literature shows the influence of domestic interest rates on banks' risk appetite (Dell' Ariccia and Marquez, 2006; Rajan, 2006; Borio and Zhu, 2008; Delis and Kouretas, 2010; Maddaloni and Peydró, 2011; Jiménez et al., 2013). On one hand, banks have a greater risktaking appetite when interest rates are low.On the other hand, an increase in interest rates can adversely affect borrowers' ability to repay loans (Jarrow and Turnbull, 2000; Carling et al., 2007; Drehmann et al., 2010; and Alessandri and Drehmann, 2010). Finally, we try to capture the possible impact of income level and growth by including GDP per capita (Per Capita) and growth in GDP per capita (Per Capita Growth).

We also control for bank-level heterogeneities. We include the share of equity capital in total assets (Capital). On one hand, an increase in equity can lower moral-hazard problems and increase banks' monitoring incentives (Berger et al., 1995,). On the other hand, higher equity can increase banks' risk-taking capacity. Equity capital can be considered a riskaversion proxy (McShane and Sharpe, 1985; Maudos and De Guevara, 2004; Koetter and Noth, 2013) and banks with higher capital ratios expect higher returns. Jensen (1986) and Harris and Raviv (1990) argue that when capital is more expensive than debt (at the margin), management might reduce operating costs to offset the higher costs of the increase in capital required by regulators. Alternatively, lower interest expense may weaken attempts to control operating expenses. Therefore, the impact of capital on efficiency is unclear.

We consider the effect of size in our study by using the logarithm of total assets (Size) as the proxy. Larger banks can benefit from scale economies and diversification (Hughes et al., 2001). They may target riskier activities where there is a benefit from safety-net subsidies (Kane, 2010). Higher competition pressure might arise where they have larger and more 
transparent clients with relatively easier access to capital markets. Larger banks may also use different technologies and business models for their operations. Thus, bank efficiency might varyacross banks ofdifferent size.We also take into account credit risk as represented by nonperforming loans to gross loans ratio (Credit Risk): a bank thatdoes not efficiently monitor its loan activities, is unlikely to be efficient in its operations (Berger and DeYoung, 1997). Finally, we capture year fixed effects using twelve year-dummy variables. ${ }^{10}$

\section{Data and Descriptive Statistics}

\subsection{DATA}

Our empirical analysis is based on country-level and bank-level data for 22 Muslim countries $^{11}$ with dual-banking systems during the 1999-2011 period. We collect the data on proportion of Muslim population from the web-site of Pew Research Centre ${ }^{12}$; uncertainty avoidance index is obtained from Hoftstede (2001); the economic freedom index is retrieved from the Heritage Foundation and the Wall Street Journal, and other country-level data are collected from the World Bank website.

The bank-level data areobtained from the Bankscope database. Bankscope classifies banks as commercial, Islamic, or other.An Islamic bank might be a commercial or a noncommercial bank. Moreover, some conventional banks have Islamic windows/branches/wings (Islamic Window Bank), and cannot be classified as either Islamic or conventional banks. Therefore, to ensure data accuracy, we retrieve information on bank type from each bank's website.

\footnotetext{
${ }^{10}$ The sample covers 13 years; however, however, we drop one year-dummy to avoid perfect multicolinearity and use twelve year-dummies in our estimations.

${ }^{11}$ Among 57 Muslim countries (i.e. OIC-member countries), we find Islamic commercial banking in 24 countries. In the following 22 Muslim countries Islamic and conventional commercial banks operate alongside each other (they have a dual-banking system): Algeria, Bahrain, Bangladesh, Brunei, Egypt, Gambia, Indonesia, Iraq, Jordan, Kuwait, Lebanon, Malaysia, Mauritania, Pakistan, Qatar, Saudi Arabia, Senegal, Syria, Tunisia, Turkey, United Arab Emirates, and Yemen. In Iran and Sudan, the commercial banking system is fully Islamic.

${ }^{12}$ Please visit http://pewforum.org/Mapping-the-Global-Muslim-Population.aspx
} 


\subsection{DESCRIPTIVE STATISTICS}

We use two subsamples of countries defined on the basis of the median value of Muslim Share. Muslim Share ranges from 51.9\% in Lebanon to $99.8 \%$ in Tunisia. The median value is $95 \%$. Countries below the median value are classified as "More Religiously Diverse Countries" and the others(in which the Muslim populationisat least 95\%) are called "Predominantly Muslim Countries".

Table 1 presents the descriptive statistics of our samplesofMore Religiously Diverse CountriesandPredominantly Muslim Countries. Islamic banks of different sizes have greater market shares in More Religiously Diverse Countries (18.54\%, 25.48\% and 21.13\% respectively for Small, Mediumand Large Islamic banks.In Predominantly Muslim Countries, the corresponding percentages are $10.68 \%, 20 \%$ and $8.20 \%$ respectively for Small, Mediumand Large Islamic banks). In both samples, the market share of Medium Islamic banks is higher than forSmalland Large Islamic banks. The market share of LargeIslamic window banks is the highest in both sub-samples. The market shares of Medium and Large Islamic window banks are higher in More Religiously Diverse Countries. Foreigners have greater ownership of commercial banks in Predominantly Muslim Countries (29.95\% versus 19.45\%).However, governments in More Religiously Diverse Countrieshave slightly larger stakes in their commercial banking systems (17.23\% versus $16.16 \%)$. The $H H I$ index shows that commercial banking industry is less concentrated in this group of countries.

The banking system in More Religiously Diverse Countriesis more developed than in Predominantly Muslim Countries.Bank Deposit, Financial System Deposit and Private Creditare $64.88 \%, 64.60 \%$ and $50.81 \%$ of GDP in More Religiously Diverse Countries.The corresponding percentages for Predominantly Muslim Countries are 35.19\%, 36.96\% and $28.09 \%$. 
We observe little difference between the two groups of countries in terms of the annual growth rate (Per Capita)i.e. $1.65 \%$ and $1.81 \%$, respectively.We do not observe a significant difference between the two samples of countries in terms of the Gini index, Poverty Ratio International, and Poverty Gap International. However, the headcount ratio (calculated based on the national poverty line) and the poverty in rural areas are higher for More Religiously Diverse Countries.

The fourth part of the table reports other country-level indicators. The Muslim Share is on average $78.22 \%$ and $97.88 \%$ across our two sub-samples. Per Capita is significantly higher for More Religiously Diverse Countries(about \$28 thousand versus \$6.67 thousand). The Uncertainty Avoidancefor More Religiously Diverse Countries is lower. We do not observe a significant difference between the two samples in terms of Inflation $7.5 \%$ in More Religiously Diverse Countries and about 9\% in Predominantly Muslim Countries). Both samples experience almost the same level of Remittance Inflow (about $6 \%$ of GDP).Overall, our descriptive statistics indicate that the two samples have different institutional and economic environments. For instance More Religiously Diverse Countries have a more developed finance sector, a higher GDP per capita, more economic freedom, a lower uncertainty avoidance index and a higher share of Islamic banks in their commercial banking market.

The last part of table 1 describes our bank-level variables for conventional banks. Conventional banks in More Religiously Diverse Countries are smaller in size, are more costefficient,have a lower capital to asset ratio (Capital) and Credit Risk.

\section{[TABLE 1]}

Table A2 in the appendix provides the breakdowns on number and average size of different types of banks across our 22 countries. The correlation matrix presented in PANEL A of Table A3 in the appendix shows no major multicollinearity problems. We study the role 
of Islamic banks in PredominantlyMuslim Countries, low-income Muslim countries and Muslim countries with comparatively high Uncertainty Avoidance on the basis of the median value of Muslim Share, Per Capitaand Uncertainty Avoidance, respectively. PANEL B in Table A3 illustrates the pair-wise correlations, which do not show any high correlations between these three sub-samples of countries ${ }^{13}$.

\section{Empirical Results}

\subsection{ISLAMIC BANKING IN PREDOMINANTLY MUSLIM COUNTRIES}

We explore the relationship between the presence of Islamic banks and the financial development and economic welfare for the sample of Predominantly Muslim Countries.We estimate Equation (1) using the fixed-effect technique, and illustrate the results in table 2 . The first three columns display our results on financial development analysis (i.e. funding mobilization and credit allocation). In the first column, we use Bank Deposit as the dependent variable and regress it on the market share of Small, MediumandLargeIslamic banks and a set of control variables, including Small, Mediumand LargeISW Share, Foreign Banks Share, State Banks Share, Inflation,Per Capita, Remittance Inflow and Trend. The results show a significantly positive relationship between the market share of MediumIslamic banks and Bank Deposit. Large ISW Share also shows apositive and significant association with the dependent variable. As expected, Inflationis negatively associatedwith Bank Deposit. The Trend variable has a positive coefficient.

In the second column, we replace Bank Deposit with Financial System Deposit as the dependent variable. The results are in line with our finding in the first column. The market share of MediumIslamic banks is positively linked to the size of funding mobilization at

\footnotetext{
${ }^{13} \mathrm{We}$ also consider economic freedom in our analysis but because the sample of countries below the median value of the Economic Freedom Index provided by the Heritage Foundation is highly correlated (0.81) with the sample of Low Income Countries we exclude this dimension per se from our estimations.
} 
thefinancial system level. Column (3) presents our analysis for Private Credit, representing credit allocation to private sector. The results show a positive relationship between Medium $I S B$ and Private Credit. Overall, the findings show a significantly positive link between the market share of MediumIslamic banks and size of financial intermediation in Predominantly Muslim Countries.

In columns (4) to (9), we explore the relationship between the market share of Islamic banks and economic welfare (i.e. economic growth, income inequality and poverty alleviation). In column (4), we use the annual growth rate of GDP per capita as a proxy for economic growth (Economic Growth) and find little relationship between the presence of Islamic banks and Economic Growth. However, we find a significantly positive association between Small ISW Share and Economic Growth. The results also show that Economic Growth increases with a rise in Per Capita. Column (5) presents our income inequality analysis as represented by the Gini index (Gini).Medium ISB Shareshowsa significantly negative link with Gini. We also observe that an increase in the market share of LargeIslamic Window Banksis associated with a decrease in Gini, whereas Small ISW Share is positively linked to income inequality.

In columns (6) to (9), we examine the relationship between the market share of Islamic banks and our proxies for poverty (Poverty Ratio International, Poverty Ratio National, Poverty Gap International and Poverty Ratio Rural). Our analyses show a negative association ofMedium ISB Sharewith Poverty Ratio National(poverty ratio defined based on national poverty line)and also Poverty Ratio Rural (poverty ration in the rural area).

Overall, we find that an increase in market share of MediumIslamic banks in PredominantlyMuslim Countriesisassociated with a higher funding mobilization and credit allocation, but lower income inequality, percentage of population below the national poverty line and headcount ratio in rural area. We carry out similar analysesfor More Religiously 
Diverse Countries and find no significant relationship between the presence of Islamic banks and our proxies for financial development and economic welfare (except for the negative link between Medium ISB Shareand Private Credit) ${ }^{14}$.

\section{[TABLE 2]}

As a robustness check, we re-estimate our model using GMM panel estimation technique and find similar results ${ }^{15}$.

\subsection{ISLAMIC BANKING IN LOW INCOME COUNTRIES}

Table 3 illustrates the estimation of Equation (1) using the sample of Low Income Countries (i.e. countries with Per Capita below the median value $\$ 6,364)^{16}$. The first three columns refer to our funds mobilization and credit allocation analysis. The results show that Medium ISB Share is positively associated with our funds mobilization proxies (i.e. Bank Deposit and Financial System Deposit). However, we find little associationbetween the presence of Islamic banks and credit allocation as represented by Private Credit.

In columns (4) to (9), we explore the relationship between the market share of Islamic banks and economic growth, income inequality and poverty. The results show that a higher market share of Medium size Islamic banks is associated with higher Economic Growth, a lower percentage of people below the international poverty line (Poverty Ratio International), lower poverty intensity (Poverty Gap International) and a lower headcount ratio in the rural area (Poverty Ratio Rural). However, we find almost no associationbetween our proxy for income inequality (i.e. Gini) and the market share of Islamic banks.

Overall, we find that the presence of Islamic banks is positively linked with financial sector development, economic growth and poverty alleviation in Low Income Countries.

\footnotetext{
${ }^{14}$ The results are not reported, but are available from the authors upon request.

${ }^{15}$ The results are not reported, but are available from the authors upon request.

${ }^{16}$ Since we make sub-samples of countries based on Per Capita, we exclude the variable Per Capita from our model in this sub-section.
} 
[TABLE 3]

\subsection{ISLAMIC BANKING IN HIGH UNCERTAINTY AVOIDANCE COUNTRIES}

Table 4 illustrates the estimation of Equation (1) using the sample of High Uncertainty Avoidance Countries (i.e. countries with an uncertainty avoidance index above the median value which is 68). We analysefunds mobilization and credit allocation in the first three columns. Medium ISB Shareshowsa positive association with Bank Deposit, Financial System Deposit and Private Credit.

In columns (4) and (5), we find no significant relationship between the presence of Islamic banks and economic growth and our income inequality index. We explore the relationship between the market share of Islamic banks and poverty indices in columns (6) to (9). We find a negative associationofMedium ISB Sharewiththe percentage of the population below the national poverty line (Poverty Ratio National) and also headcount ratio in the rural area (Poverty Ratio Rural).

Overall, we find that the market share of Medium size Islamic banks is positively linked with financial sector development. We also find some evidence,which suggests that the growth of Islamic banking is associated with poverty alleviation particularly in rural areas. As a further robustness check, we exclude Lebanon as it suffered from civil war during our period of study and investigate whether the findings still hold. The results indicate no significant change ${ }^{17}$.

[TABLE 4]

\subsection{OTHER ISSUES}

\subsubsection{ISLAMIC BANKING IN HIGH INFLAITON COUNTRIES}

\footnotetext{
${ }^{17}$ The results are not reported, but are available from the authors upon request.
} 
It can be argued that Islamic banks might have a different impact during periods of high inflation. Islamic banks might hold more cash reserves, because they have some limitation for investment, e.g. they cannot invest in interest-base bonds (see e.g. Abedifar et al., 2013); however, they might use more commodities as collateral, because they tend to finance the real economy and tangible assets. Hence, the link between the presence of Islamic banks and financial development and economic welfare during a relatively high inflationary period is not straightforward.On the one hand, greater cash reserves holding would devalue Islamic banks' assets to a greater extentthan for their conventional counterparts.On the other hand, widespread use of commodities can be a safe cushion against inflation. To address this issue, we estimate our model (Equation (1)) for a subsample of countries that experienced relatively high inflation (on the basis of the median value of inflation in our samples $7.09 \%$ ). The results are shown in table A4 of the appendix. We find no significant relationship between the market share of Islamic banks and financial development; however, we observe a negative link between Large ISB Share and Economic Growth.

\subsubsection{ISLAMIC BANKING BEFORE AND AFTER THE GLOBAL FINANCIAL CRISIS}

We investigate whether and how our findings change when we exclude the global financial crisis of 2007-08 from our analysis. We consider two sub-periods for Predominantly Muslim Countries: the period before the global financial crisis (i.e. 1999-2007) and during the global recession thereafter $\left(2008-2012^{18}\right)$. The results are presented in Table A5 of the appendix. We give our estimatesof the model (Equation (1)) for the two periods: columns (1) to (4) and (5) to (8). The first four columns show a positive link between Medium ISB Share and funds mobilization proxies (i.e. Bank Deposit and Financial System Deposit) as well as Economic

\footnotetext{
${ }^{18}$ A number of countries in our sample also experienced the turmoil caused by the so-called "Arab Spring" in late 2010 .
} 
Growth. The relationship is economically stronger than for the whole period (see sub-section 4.1.)

In the recession period, we find that the market share of Small Islamic banks is positively associated with funds mobilization and credit allocation, whereas Large ISB Shareshowsa negative link with our proxies for financial development. The estimations show no significant link between the presence of Islamic banks and economic growth.

\subsection{EFFICIENCY OF CONVENTIONAL BANKS}

We estimate Equation (2) using the ratio of total noninterest expense to total operating income (Inefficiency) as the proxy. We estimate our model for More Religiously Diverse CountriesandPredominantly Muslim Countries subsamples. Table 5 presents the estimations.

Columns (1) to (4) illustrate the analysis for More Religiously Diverse Countries. In the first column we regress Inefficiency on Small, Mediumand Large ISB Share while controlling for Small, Mediumand Large ISW Share. Country-level variables including HHI, Domestic Interest Rate, Per Capita, and Per Capita Growth are added to the model in column (2). In column (3), we control for Capital, Sizeand Credit Risk of conventional banks. In column (4) we add year-dummies. The results show no significant relationship between the market share of Islamic banks and Inefficiency.However, we find that Medium and Large ISW Share is negatively linked to Inefficiency which suggests that in countries with a relatively lower Muslim share in their population, conventional banksmaybe more influenced by Islamic Window Banks. We also find that an increase in Per Capita is associated with a decline in Inefficiency.However, HHI showsno relationship with the dependent variable and hence does not support either the Quite-Life or Efficient-Structure hypotheses.

In columns (5) to (8) we estimate our model for Predominantly Muslim Countries with the same specifications ascolumns (1) to (4). We find that Large ISB Share is negatively 
linked to Inefficiency. The negative coefficient of Medium ISB Sharebecomes insignificant when we add our bank-level control variables in column (8).Contrary to our finding for More Religiously Diverse Countries, Islamic Window Banksshowno significant relationship with the dependent variable. Finally, we observe that banks with more Credit Risk are less efficient.

[TABLE 5]

\section{Summary and Conclusion}

This paper investigates whether the presence of Islamic commercial banks and their conventional counterparts in the same market can foster the development of the overall commercial banking sector and economic welfare. We also explore the possible implications for conventional banks operating in a dual-banking system.

During recent decades, as Islamic banking has grown in many Muslim countries, a dual-banking system has emerged in which both Islamic and conventional banks share the market. Islamic financial institutions offer Sharia-compatible financial products and services. This could have lessened the potential for financial exclusion, by reaching out to Muslims who avoid conventional borrowing and lending instruments.

Islamic banks behave differently from their conventional counterparts in several ways. Specifically, they are not authorized to engage with speculative activities. They must act as agents of their investment accountholders by allocating their savings to profitable projects. They tend tobe more risk-averse and have a stronger preference for investing in the real economy. Moreover, the coexistence of Islamic and conventional banking could increase the efficiency of the whole banking system by improving competition. 
We study 22 Muslim countries with a dual-banking system during the 1999-2011 period. Due to considerable heterogeneity,we split the countries into two subsamples based on three factors: the share of the Muslims in population, population's wealth and culture.

We find that the market share of medium-size Islamic banks in predominantly Muslim countries is positively linked with funds mobilization and private credit allocation, and negatively linked with income inequality, percentage of population below the national poverty line and headcount ratio in the rural area.The analysis of relatively low income countries shows that the presence of medium-size Islamic banks is associated with a higher level of funds mobilization, economic growth and poverty alleviation. In countries with a relatively high uncertainty avoidance index, medium-size Islamic banks have a positive relationship with funds mobilization and private credit allocation and a negative association with headcount ratio based on national poverty line and poverty ratio in rural area.

We also investigate the relationship between the presence of Islamic banks and the efficiency of conventional banks. We find that the market share of large Islamic banks is positively linked with the efficiency of conventional banks in predominantly Muslim countries. However, in more religiously diverse Muslim countries, the market share of conventional banks with Islamic window/branches is positively linked to the efficiency of purely conventional banks.

Overall, the results are consistent with the view that the presence of Islamic banks can foster access to finance and financial deepening, and improve economic welfare particularly in countries with a predominantly Muslim population,higher uncertainty avoidance index and acomparatively low GDP per capita. The findings are in line with the existing literature onfinance and development. 


\section{Appendices}

\section{Table A1.Variable Description}

This table presents descriptions of variables used in this study.

\begin{tabular}{|c|c|c|}
\hline Variables & Description & Source \\
\hline \multicolumn{3}{|c|}{ Commercial Bank Structure } \\
\hline Small ISB Share & $\begin{array}{l}\text { Small Islamic banks' assets as a percentage of total assets of all commercial banks. Small Islamic } \\
\text { banks are Islamic banks with total assets below } \$ 100 \text { million. }\end{array}$ & $\begin{array}{l}\text { Bankscope and banks } \\
\text { websites. }\end{array}$ \\
\hline $\begin{array}{l}\text { Medium ISB } \\
\text { Share }\end{array}$ & $\begin{array}{l}\text { Medium Islamic banks' assets as a percentage of total assets of all commercial banks. Medium } \\
\text { Islamic banks are Islamic banks with total assets above } \$ 100 \text { million and below } \$ 1 \text { billion. }\end{array}$ & $\begin{array}{l}\text { Bankscope and banks } \\
\text { websites. }\end{array}$ \\
\hline Large ISB Share & $\begin{array}{l}\text { Large Islamic banks' assets as a percentage of total assets of all commercial banks. Large Islamic } \\
\text { banks are Islamic banks with total assets above } \$ 1 \text { billion. }\end{array}$ & $\begin{array}{l}\text { Bankscope and banks } \\
\text { websites. }\end{array}$ \\
\hline Small ISW Share & $\begin{array}{l}\text { Total assets of small commercial banks offering both Islamic and conventional products as a } \\
\text { percentage of total assets of all commercial banks. Small commercial banks are banks with total } \\
\text { assets below } \$ 100 \text { million. }\end{array}$ & $\begin{array}{l}\text { Bankscope and banks } \\
\text { websites. }\end{array}$ \\
\hline $\begin{array}{l}\text { Medium ISW } \\
\text { Share }\end{array}$ & $\begin{array}{l}\text { Total assets of medium-size commercial banks offering both Islamic and conventional products as } \\
\text { a percentage of total assets of all commercial banks. Medium-size commercial banks are banks } \\
\text { with total assets above } \$ 100 \text { million and below } \$ 1 \text { billion. }\end{array}$ & $\begin{array}{l}\text { Bankscope and banks } \\
\text { websites. }\end{array}$ \\
\hline $\begin{array}{l}\text { Large ISW } \\
\text { Share }\end{array}$ & $\begin{array}{l}\text { Total assets of large commercial banks offering both Islamic and conventional products as a } \\
\text { percentage of total assets of all commercial banks. Large commercial banks are banks with total } \\
\text { assets above } \$ 1 \text { billion. }\end{array}$ & $\begin{array}{l}\text { Bankscope and banks } \\
\text { websites. }\end{array}$ \\
\hline $\begin{array}{l}\text { Foreign Banks } \\
\text { Share }\end{array}$ & Foreign-owned bank assets as a percentage of total assets of commercial banks. & $\begin{array}{l}\text { Bankscope and banks } \\
\text { websites. }\end{array}$ \\
\hline $\begin{array}{l}\text { State Banks } \\
\text { Share }\end{array}$ & State-owned bank assets as a percentage of total assets of commercial banks. & $\begin{array}{l}\text { Bankscope and banks } \\
\text { websites. }\end{array}$ \\
\hline HHI & $\begin{array}{l}\text { Hirschman-Herfindahl index (HHI) is a proxy for market concentration: } H H I_{c, t}=100 \times \\
\sum_{i=1}^{n}\left(\text { Total_Assets }_{i, t, c} / \sum_{i=1}^{n} \text { Total_Assets }_{i, t, c}\right)^{2} \text {. It has a value between } 0 \text { and } 100 \text {. Higher values } \\
\text { indicate that the market is more concentrated. }\end{array}$ & $\begin{array}{l}\text { Bankscope and banks } \\
\text { websites. }\end{array}$ \\
\hline \multicolumn{3}{|c|}{ Funding Mobilization and Allocation } \\
\hline Bank Deposit & The ratio of commercial bank deposits to GDP. & $\begin{array}{l}\text { The World Bank } \\
\text { website. }\end{array}$ \\
\hline $\begin{array}{l}\text { Financial } \\
\text { System Deposit }\end{array}$ & The ratio of financial system deposits to GDP. & $\begin{array}{l}\text { The World Bank } \\
\text { website. }\end{array}$ \\
\hline Private Credit & The ratio of private credit to GDP. & $\begin{array}{l}\text { The World Bank } \\
\text { website. }\end{array}$ \\
\hline \multicolumn{3}{|c|}{ Economic Growth, Income Inequality \& Poverty Index } \\
\hline $\begin{array}{l}\text { Economic } \\
\text { Growth }\end{array}$ & The annual growth rate of GDP per capita. & $\begin{array}{l}\text { The World Bank } \\
\text { website. }\end{array}$ \\
\hline Gini & The Gini coefficient used as a measure of income inequality. & $\begin{array}{l}\text { The World Bank } \\
\text { website. }\end{array}$ \\
\hline $\begin{array}{l}\text { Poverty Ratio } \\
\text { International }\end{array}$ & Percentage of population below the international poverty line defined as $\$ 1.25$ a day (PPP). & $\begin{array}{l}\text { The World Bank } \\
\text { website. }\end{array}$ \\
\hline $\begin{array}{l}\text { Poverty Ratio } \\
\text { National }\end{array}$ & Percentage of population below the national poverty line. & $\begin{array}{l}\text { The World Bank } \\
\text { website. }\end{array}$ \\
\hline Poverty Gap & The intensity of poverty at the international poverty line. & $\begin{array}{l}\text { The World Bank } \\
\text { website. }\end{array}$ \\
\hline $\begin{array}{l}\text { Poverty Ratio } \\
\text { Rural }\end{array}$ & Percentage of rural population below the rural poverty line. & $\begin{array}{l}\text { The World Bank } \\
\text { website. }\end{array}$ \\
\hline \multicolumn{3}{|c|}{ Other Country Level Heterogeneities } \\
\hline Muslim Share & Proportion of Muslims in a country's population. & Pew Research Centre. \\
\hline Per Capita & GDP per capita (thousands \$), measured by PPP approach (constant 2005 international). & $\begin{array}{l}\text { The World Bank } \\
\text { website. }\end{array}$ \\
\hline Uncertainty & Society's tolerance for uncertainty and ambiguity. & The website of Geert \\
\hline
\end{tabular}




\begin{tabular}{|c|c|c|}
\hline Avoidance Index & & and Gert Jan Hofstede. \\
\hline $\begin{array}{l}\text { Economic } \\
\text { Freedom Index }\end{array}$ & It measures the degree of freedom of a country. & $\begin{array}{l}\text { the Heritage } \\
\text { Foundation and the } \\
\text { Wall Street Journal. }\end{array}$ \\
\hline Inflation & The annual inflation rate measured by GDP deflator. & $\begin{array}{l}\text { The World Bank } \\
\text { website. }\end{array}$ \\
\hline $\begin{array}{l}\text { Remittance } \\
\text { Inflow }\end{array}$ & Remittance inflow to GDP. & $\begin{array}{l}\text { The World Bank } \\
\text { website. }\end{array}$ \\
\hline $\begin{array}{l}\text { Domestic } \\
\text { Interest Rate }\end{array}$ & $\begin{array}{l}\text { Deposit interest rate provided by the World Bank website; for years and countries with missing } \\
\text { observations, the data is obtained from the central bank websites. }\end{array}$ & $\begin{array}{l}\text { The World Bank } \\
\text { website and the } \\
\text { websites of central } \\
\text { banks. }\end{array}$ \\
\hline \multicolumn{3}{|c|}{ Bank-Level Analysis } \\
\hline Inefficiency & The ratio of total noninterest expense to total operating revenue. & Bankscope \\
\hline Size & The logarithm of total assets. & Bankscope \\
\hline Capital & The ratio of equity capital to asset. & Bankscope \\
\hline Credit Risk & The ratio of non-performing loans to gross loans. & Bankscope \\
\hline
\end{tabular}


Table A2. Commercial Banking Market Structure across Countries

This table presents the average Muslim Share, Change in Per Capita Growth, Number and average size of Islamic, Islamic Window and Conventional Banks for our 22 countries of study.

\begin{tabular}{|c|c|c|c|c|c|c|c|c|}
\hline Countries & $\begin{array}{l}\text { Muslim } \\
\text { Share }\end{array}$ & $\begin{array}{l}\text { Change in } \\
\text { Per Capita Growth }\end{array}$ & $\begin{array}{c}\text { Number of } \\
\text { Islamic Banks }\end{array}$ & $\begin{array}{c}\text { Number of } \\
\text { Islamic Window Banks }\end{array}$ & $\begin{array}{c}\text { Number of } \\
\text { Conventional Banks }\end{array}$ & $\begin{array}{c}\text { Islamic Banks } \\
\text { Average Size }\end{array}$ & $\begin{array}{c}\text { Islamic Window Banks } \\
\text { Average Size }\end{array}$ & $\begin{array}{c}\text { Conventional Banks } \\
\text { Average Size }\end{array}$ \\
\hline Algeria & 98.2 & -0.07 & 2 & 0 & 8 & 370 & -- & 4,520 \\
\hline Bahrain & 81.2 & -0.24 & 4 & 2 & 3 & 4,393 & 2,124 & 9,894 \\
\hline Bangladesh & 90.4 & 0.20 & 4 & 7 & 15 & 695 & 1,081 & 1,575 \\
\hline Brunei & 51.9 & -0.19 & 2 & 0 & 1 & 2,838 & -- & 856 \\
\hline Egypt & 94.7 & -0.35 & 2 & 5 & 17 & 3,696 & 4,024 & 3,750 \\
\hline Gambia & 95.3 & -0.90 & 0 & 0 & 3 & 12 & -- & 62 \\
\hline Indonesia & 88.1 & 0.47 & 3 & 6 & 45 & 891 & 3,752 & 3,732 \\
\hline Iraq & 98.9 & 0.87 & 2 & 0 & 4 & 616 & -- & 2,646 \\
\hline Jordan & 98.8 & -0.10 & 2 & 0 & 9 & 972 & -- & 4,985 \\
\hline Kuwait & 86.4 & 0.71 & 2 & 0 & 4 & 8,175 & 4,797 & 8,876 \\
\hline Lebanon & 59.7 & 0.23 & 1 & 1 & 32 & 906 & 5,309 & 2,331 \\
\hline Malaysia & 61.4 & -0.02 & 9 & 8 & 11 & 4,784 & 8,083 & 6,426 \\
\hline Mauritania & 99.2 & -0.28 & 1 & 2 & 4 & 74 & 1,434 & 1,789 \\
\hline Pakistan & 96.4 & -0.01 & 2 & 8 & 7 & 1,955 & 3,747 & 1,333 \\
\hline Qatar & 77.5 & 0.47 & 3 & 0 & 5 & 5,419 & 301 & 6,446 \\
\hline Saudi Arabia & 97.1 & 0.75 & 3 & 6 & 1 & 12,200 & 15,100 & 14,600 \\
\hline Senegal & 95.9 & -0.38 & 1 & 0 & 9 & 498 & -- & 888 \\
\hline Syria & 92.8 & 0.01 & 1 & 0 & 6 & 931 & -- & 12,100 \\
\hline Tunisia & 99.8 & -0.53 & 2 & 1 & 9 & 343 & 531 & 4,340 \\
\hline Turkey & 98.6 & 1.02 & 2 & 0 & 23 & 4,270 & -- & 13,600 \\
\hline UAE & 76.0 & 0.03 & 7 & 2 & 14 & 4,974 & 8,431 & 7,120 \\
\hline Yemen & 99.0 & -1.49 & 3 & 0 & 4 & 777 & -- & 702 \\
\hline
\end{tabular}




\section{TABLE A3.Correlation matrix}

PANEL A.

This panel presents the pair-wise correlation among the independent variables used in our analysis.

\begin{tabular}{|c|c|c|c|c|c|c|c|c|c|c|c|}
\hline & $\begin{array}{l}\text { Small ISB } \\
\text { Share }\end{array}$ & $\begin{array}{l}\text { Medium ISB } \\
\text { Share }\end{array}$ & $\begin{array}{l}\text { Large ISB } \\
\text { Share }\end{array}$ & $\begin{array}{c}\text { Small ISW } \\
\text { Share }\end{array}$ & $\begin{array}{l}\text { Medium ISW } \\
\text { Share }\end{array}$ & $\begin{array}{c}\text { Large ISW } \\
\text { Share }\end{array}$ & $\begin{array}{c}\text { Foreign Banks } \\
\text { Share }\end{array}$ & $\begin{array}{c}\text { State Banks } \\
\text { Share }\end{array}$ & Inflation & Per Capita & Remittance Inflow \\
\hline Small ISB Share & 1.00 & & & & & & & & & & \\
\hline Medium ISB Share & 0.22 & 1.00 & & & & & & & & & \\
\hline Large ISB Share & 0.12 & 0.30 & 1.00 & & & & & & & & \\
\hline Small ISW Share & -0.02 & 0.02 & 0.01 & 1.00 & & & & & & & \\
\hline Medium ISW Share & 0.06 & -0.07 & 0.20 & 0.23 & 1.00 & & & & & & \\
\hline Large ISW Share & -0.04 & -0.15 & -0.07 & 0.34 & 0.34 & 1.00 & & & & & \\
\hline Foreign Banks Share & 0.13 & 0.02 & -0.15 & -0.05 & -0.18 & -0.17 & 1.00 & & & & \\
\hline State Banks Share & -0.02 & 0.09 & 0.15 & -0.02 & -0.01 & 0.03 & -0.27 & 1.00 & & & \\
\hline Inflation Rate & 0.02 & -0.03 & 0.11 & -0.01 & -0.02 & -0.04 & -0.16 & 0.10 & 1.00 & & \\
\hline Per Capita & 0.05 & 0.24 & 0.47 & -0.14 & -0.05 & -0.10 & -0.31 & 0.03 & 0.09 & 1.00 & \\
\hline Remittance Inflow & -0.11 & -0.01 & -0.16 & -0.13 & -0.21 & -0.26 & -0.02 & -0.24 & -0.20 & -0.18 & 1.00 \\
\hline
\end{tabular}

\section{PANEL B.}

This panel presents the pair-wise correlation among the indicators used for our sub-sampling.

\begin{tabular}{|c|c|c|c|c|}
\hline & $\begin{array}{c}\text { Muslim Share } \\
\text { Above Median Countries }\end{array}$ & $\begin{array}{c}\text { Per Capita } \\
\text { Below Median Countries }\end{array}$ & $\begin{array}{l}\text { Uncertainty Avoidance Index } \\
\text { Above Median Countries }\end{array}$ & $\begin{array}{l}\text { Economic Freedom Index } \\
\text { Below Median Countries }\end{array}$ \\
\hline Muslim Share - Above Median Countries & 1.00 & & & \\
\hline Per Capita - Below Median Countries & 0.28 & 1.00 & & \\
\hline Uncertainty Avoidance Index - Above Median Countries & 0.11 & -0.36 & 1.00 & \\
\hline Economic Freedom Index - Below Median Countries & 0.28 & 0.81 & -0.36 & 1.00 \\
\hline
\end{tabular}




\section{Table A4. Islamic Banking in High Inflation Countries}

This table illustrates the estimation of the equation (1) for the sample of High Inflation Countries:

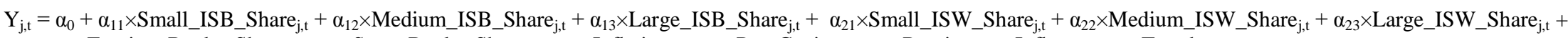
$\alpha_{3} \times$ Foreign_Banks_Share $_{\mathrm{j}, \mathrm{t}}+\alpha_{4} \times$ State_Banks_Share $_{\mathrm{j}, \mathrm{t}}+\alpha_{5} \times$ Inflation $_{\mathrm{j}, \mathrm{t}}+\alpha_{6} \times$ Per_Capita $_{\mathrm{j}, \mathrm{t}}+\alpha_{7} \times$ Remittance_Inflow $_{\mathrm{j}, \mathrm{t}}+\alpha_{8} \times \operatorname{Trend}_{\mathrm{t}}+\varepsilon_{\mathrm{j}, \mathrm{t}}$

We split our sample into two groups on the basis of the median proportion of Inflation. Countries above the median value are classified in one group (High Inflation Countries). The median value is $7.09 \%$

We regress our dependent variables on our variable of interest (i.e., Small ISB Share, Medium ISB Share and Large ISB Share) and control variables. In columns (1) to (3), we study the relationship between our variables of interest and development of financial intermediation. Columns (4) to (9) present our analysis for economic growth, income inequality and poverty index.

We employ the fixed-effect technique for our estimation. Standard errors are clustered at the country level. Robust z-statistics are reported in parentheses. $* * *$, $* *$, and $*$ indicate significance at $1 \%, 5 \%$, and $10 \%$ respectively. See table A1 for variable definitions.

\begin{tabular}{|c|c|c|c|c|c|c|c|c|}
\hline & \multicolumn{3}{|c|}{ Funding Mobilization and Allocation } & \multicolumn{5}{|c|}{ Economic Growth, Income Inequality and Poverty Index } \\
\hline & Bank Deposit & Financial System Deposit & Private Credit & Economic Growth & Gini & Poverty Ratio International & Poverty Ratio National & Poverty Gap International \\
\hline Variables & (1) & (2) & (3) & (4) & (5) & (6) & (7) & (8) \\
\hline Small ISB Share & $\begin{array}{l}-0.016 \\
(-0.72)\end{array}$ & $\begin{array}{l}-0.016 \\
(-0.65)\end{array}$ & $\begin{array}{l}-0.030 \\
(-0.82)\end{array}$ & $\begin{array}{l}-0.028 \\
(-1.54)\end{array}$ & $\begin{array}{l}-0.046 \\
(-0.94)\end{array}$ & $\begin{array}{l}0.022 \\
(1.26)\end{array}$ & $\begin{array}{l}-0.016 \\
(-1.07)\end{array}$ & $\begin{array}{c}-0.041 * * * \\
(-4.13)\end{array}$ \\
\hline Medium ISB Share & $\begin{array}{l}0.071 \\
(1.60)\end{array}$ & $\begin{array}{l}0.065 \\
(1.17)\end{array}$ & $\begin{array}{l}0.011 \\
(0.14)\end{array}$ & $\begin{array}{l}0.023 \\
(1.00)\end{array}$ & $\begin{array}{l}0.132 \\
(0.94)\end{array}$ & $\begin{array}{c}-0.139 * * * \\
(-6.88)\end{array}$ & $\begin{array}{l}0.048 \\
(1.32)\end{array}$ & $\begin{array}{l}0.162 \\
(0.42)\end{array}$ \\
\hline Large ISB Share & $\begin{array}{l}-0.008 \\
(-0.19)\end{array}$ & $\begin{array}{l}-0.025 \\
(-0.75)\end{array}$ & $\begin{array}{l}-0.039 \\
(-1.21)\end{array}$ & $\begin{array}{c}-0.035^{* *} \\
(-2.49)\end{array}$ & $\begin{array}{l}0.099 \\
(0.05)\end{array}$ & $\begin{array}{l}0.035 \\
(0.91)\end{array}$ & $\begin{array}{l}0.097 \\
(0.17)\end{array}$ & $\begin{array}{l}-0.599 \\
(-0.30)\end{array}$ \\
\hline Small ISW Share & $\begin{array}{l}0.062 \\
(1.50)\end{array}$ & $\begin{array}{l}0.067 \\
(1.67)\end{array}$ & $\begin{array}{l}0.030 \\
(1.15)\end{array}$ & $\begin{array}{l}0.018 \\
(1.06)\end{array}$ & $\begin{array}{c}-0.083^{* * *} \\
(-3.07)\end{array}$ & $\begin{array}{c}-0.035 * * \\
(-2.91)\end{array}$ & $\begin{array}{c}-0.029 * * \\
(-2.93)\end{array}$ & $\begin{array}{l}-0.190 \\
(-0.40)\end{array}$ \\
\hline Medium ISW Share & $\begin{array}{l}0.107 \\
(1.50)\end{array}$ & $\begin{array}{l}0.127 \\
(1.68)\end{array}$ & $\begin{array}{l}0.071 \\
(0.67)\end{array}$ & $\begin{array}{l}0.045 \\
(1.65)\end{array}$ & $\begin{array}{c}0.464 * * * \\
(7.51)\end{array}$ & $\begin{array}{c}-0.331 * * * \\
(-24.81)\end{array}$ & $\begin{array}{c}0.149 * * * \\
(8.65)\end{array}$ & $\begin{array}{l}-0.224 \\
(-0.51)\end{array}$ \\
\hline Large ISW Share & $\begin{array}{l}0.045 \\
(0.43)\end{array}$ & $\begin{array}{l}0.053 \\
(0.46)\end{array}$ & $\begin{array}{c}0.186^{*} \\
(1.85)\end{array}$ & $\begin{array}{l}0.028 \\
(0.97)\end{array}$ & $\begin{array}{c}0.221 * * * \\
(4.26)\end{array}$ & $\begin{array}{l}0.016 \\
(1.04)\end{array}$ & $\begin{array}{c}0.056^{* * *} \\
(3.13)\end{array}$ & $\begin{array}{l}0.283 \\
(0.46)\end{array}$ \\
\hline Foreign Banks Share & $\begin{array}{l}-0.140 \\
(-1.70)\end{array}$ & $\begin{array}{l}-0.151 \\
(-1.58)\end{array}$ & $\begin{array}{l}-0.131 \\
(-1.23)\end{array}$ & $\begin{array}{l}0.037 \\
(1.03)\end{array}$ & $\begin{array}{c}-0.221 * * \\
(-3.09)\end{array}$ & $\begin{array}{l}-0.079 \\
(-1.04)\end{array}$ & $\begin{array}{c}-0.062 * * * \\
(-4.48)\end{array}$ & $\begin{array}{c}-0.404 * * * \\
(-4.09)\end{array}$ \\
\hline State Banks Share & $\begin{array}{c}-0.261^{* *} \\
(-2.98)\end{array}$ & $\begin{array}{c}-0.272 * * \\
(-2.51)\end{array}$ & $\begin{array}{l}-0.187 \\
(-1.28)\end{array}$ & $\begin{array}{l}-0.006 \\
(-0.16)\end{array}$ & $\begin{array}{l}-0.337 \\
(-1.63)\end{array}$ & $\begin{array}{c}0.256 * * * \\
(5.34)\end{array}$ & $\begin{array}{l}-0.110^{*} \\
(-2.03)\end{array}$ & $\begin{array}{l}-0.049 \\
(-0.31)\end{array}$ \\
\hline Inflation & $\begin{array}{c}0.986 * * \\
(2.96)\end{array}$ & $\begin{array}{c}1.046 * * * * \\
(3.08)\end{array}$ & $\begin{array}{l}0.366 \\
(0.90)\end{array}$ & $\begin{array}{c}0.272 * \\
(1.83)\end{array}$ & $\begin{array}{c}1.991 * * * \\
(10.17)\end{array}$ & $\begin{array}{c}-3.075 * * * \\
(-13.76)\end{array}$ & $\begin{array}{c}0.653 * * * \\
(8.40)\end{array}$ & $\begin{array}{c}-5.362^{* * *} \\
(-2.53)\end{array}$ \\
\hline Per Capita & $\begin{array}{l}-1.038 \\
(-0.97)\end{array}$ & $\begin{array}{l}-0.604 \\
(-0.48)\end{array}$ & $\begin{array}{l}0.004 \\
(0.00)\end{array}$ & $\begin{array}{c}0.483 * * \\
(2.30)\end{array}$ & $\begin{array}{l}-0.961 \\
(-0.50)\end{array}$ & $\begin{array}{c}-3.111 * * * \\
(-7.82)\end{array}$ & $\begin{array}{l}-0.231 \\
(-0.44)\end{array}$ & $\begin{array}{l}-8.335^{*} \\
(-1.99)\end{array}$ \\
\hline Remittance Inflow & $\begin{array}{l}-0.105 \\
(-0.15)\end{array}$ & $\begin{array}{l}-0.137 \\
(-0.18)\end{array}$ & $\begin{array}{l}0.675 \\
(1.31)\end{array}$ & $\begin{array}{l}0.037 \\
(0.21)\end{array}$ & $\begin{array}{c}-2.316 * * * \\
(-4.32)\end{array}$ & $\begin{array}{l}0.014 \\
(0.05)\end{array}$ & $\begin{array}{c}-0.768 * * * \\
(-6.72)\end{array}$ & $\begin{array}{l}1.784 \\
(1.24)\end{array}$ \\
\hline Constant & $\begin{array}{c}43.092 * * * \\
(3.64)\end{array}$ & $\begin{array}{c}42.294 * * * \\
(3.45)\end{array}$ & $\begin{array}{c}22.465^{*} \\
(2.08)\end{array}$ & $\begin{array}{l}-3.375 \\
(-1.59)\end{array}$ & $\begin{array}{c}26.069 \\
(1.34)\end{array}$ & $\begin{array}{c}55.223 * * * \\
(17.81)\end{array}$ & $\begin{array}{l}6.373 \\
(1.27)\end{array}$ & $\begin{array}{c}89.010^{* * *} \\
(3.78)\end{array}$ \\
\hline Observations & 79 & 76 & 78 & 83 & 25 & 24 & 25 & 22 \\
\hline R-squared & 0.370 & 0.316 & 0.287 & 0.216 & 0.916 & 0.984 & 0.909 & 0.965 \\
\hline Number of Country & 14 & 14 & 14 & 15 & 9 & 7 & 9 & 7 \\
\hline
\end{tabular}


Table A5. Islamic Banking - the Global Financial Crisis

This table illustrates the estimation of the equation (1) before and during the global financial crisis 2007-08:

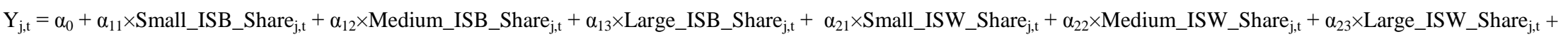
$\alpha_{3} \times$ Foreign_Banks_Share $_{\mathrm{j}, \mathrm{t}}+\alpha_{4} \times$ State_Banks_Share $_{\mathrm{j}, \mathrm{t}}+\alpha_{5} \times$ Inflation $_{\mathrm{j}, \mathrm{t}}+\alpha_{6} \times$ Per_Capita $_{\mathrm{j}, \mathrm{t}}+\alpha_{7} \times$ Remittance_Inflow $_{\mathrm{j}, \mathrm{t}}+\alpha_{8} \times \operatorname{Trend}_{\mathrm{t}}+\varepsilon_{\mathrm{j}, \mathrm{t}}$

We split our sample our sample of Predominantly Muslim Countries into two groups. The analysis of the period before the global financial crisis, i.e. 1999-2007, is presented in columns (1) to (4). Columns (5) to (8) present the study of the recent global recession, i.e. 2008-2011.

We regress our dependent variables on our variable of interest (i.e., Small ISB Share, Medium ISB Share and Large ISB Share) and control variables. In columns (1) to (3), we study the relationship between our variables of interest and development of financial intermediation (represented by Bank Deposit, Financial System Deposit and Private Credit) Column (4) illustrates the estimation for economic growth. Columns (5) to (8) present the analysis for the period of the global recession, i.e. 2008-2011, with the same specifications of columns (1) to (4).

We employ the fixed-effect technique for our estimation. Standard errors are clustered at the country level. Robust z-statistics are reported in parentheses. $* * *, * *$, and $*$ indicate significance at $1 \%, 5 \%$, and $10 \%$ respectively. See table A1 for variable definitions.

\begin{tabular}{|c|c|c|c|c|c|c|c|c|}
\hline & \multicolumn{4}{|c|}{ Before the Global Financial Crisis (1999-2007) } & \multicolumn{4}{|c|}{ The Global Recession (2008-2011) } \\
\hline & Bank Deposit & Financial System Deposit & Private Credit & Economic Growth & Bank Deposit & Financial System Deposit & Private Credit & Economic Growth \\
\hline Variables & (1) & (2) & (3) & (4) & (5) & $(6)$ & (7) & (8) \\
\hline Small ISB Share & $\begin{array}{l}0.034 \\
(0.66)\end{array}$ & $\begin{array}{l}0.003 \\
(0.08)\end{array}$ & $\begin{array}{l}-0.026 \\
(-1.11)\end{array}$ & $\begin{array}{l}0.018 \\
(0.76)\end{array}$ & $\begin{array}{c}0.318^{* * * *} \\
(4.44)\end{array}$ & $\begin{array}{c}0.309^{* * * *} \\
(3.84)\end{array}$ & $\begin{array}{c}0.163^{* * *} \\
(2.42)\end{array}$ & $\begin{array}{l}-0.026 \\
(-0.47)\end{array}$ \\
\hline Medium ISB Share & $\begin{array}{c}0.057 * * * \\
(4.94)\end{array}$ & $\begin{array}{c}0.055^{*} \\
(2.06)\end{array}$ & $\begin{array}{l}0.036 \\
(1.72)\end{array}$ & $\begin{array}{c}0.038 * * * \\
(3.80)\end{array}$ & $\begin{array}{c}-0.044 * \\
(-2.08)\end{array}$ & $\begin{array}{l}-0.036 \\
(-1.32)\end{array}$ & $\begin{array}{l}-0.026 \\
(-0.67)\end{array}$ & $\begin{array}{l}0.023 \\
(0.42)\end{array}$ \\
\hline Large ISB Share & $\begin{array}{l}0.025 \\
(0.49)\end{array}$ & $\begin{array}{l}-0.007 \\
(-0.16)\end{array}$ & $\begin{array}{l}-0.015 \\
(-0.63)\end{array}$ & $\begin{array}{l}0.025 \\
(1.63)\end{array}$ & $\begin{array}{c}-0.361 * * * \\
(-4.87)\end{array}$ & $\begin{array}{c}-0.361 * * * \\
(-4.46)\end{array}$ & $\begin{array}{c}-0.167 * * \\
(-3.09)\end{array}$ & $\begin{array}{l}-0.056 \\
(-0.88)\end{array}$ \\
\hline Small ISW Share & $\begin{array}{l}-0.032 \\
(-1.79)\end{array}$ & $\begin{array}{l}-0.032 \\
(-1.51)\end{array}$ & $\begin{array}{c}0.031 * \\
(2.08)\end{array}$ & $\begin{array}{l}-0.006 \\
(-0.67)\end{array}$ & $\begin{array}{l}-0.090 \\
(-1.49)\end{array}$ & $\begin{array}{l}-0.083 \\
(-1.61)\end{array}$ & $\begin{array}{c}-0.135^{* * * *} \\
(-3.48)\end{array}$ & $\begin{array}{l}0.023 \\
(0.48)\end{array}$ \\
\hline Medium ISW Share & $\begin{array}{l}0.008 \\
(0.14)\end{array}$ & $\begin{array}{l}0.026 \\
(0.45)\end{array}$ & $\begin{array}{c}0.101 * * \\
(2.81)\end{array}$ & $\begin{array}{c}-0.067 * * \\
(-3.18)\end{array}$ & $\begin{array}{l}0.191 \\
(1.46)\end{array}$ & $\begin{array}{l}0.134 \\
(1.59)\end{array}$ & $\begin{array}{l}0.078 \\
(0.49)\end{array}$ & $\begin{array}{l}0.158 \\
(0.65)\end{array}$ \\
\hline Large ISW Share & $\begin{array}{l}-0.007 \\
(-0.07)\end{array}$ & $\begin{array}{l}-0.027 \\
(-0.32)\end{array}$ & $\begin{array}{l}-0.054 \\
(-1.40)\end{array}$ & $\begin{array}{l}-0.018 \\
(-0.70)\end{array}$ & $\begin{array}{c}0.259^{* *} \\
(2.72)\end{array}$ & $\begin{array}{l}-0.043 \\
(-0.09)\end{array}$ & $\begin{array}{c}0.270 * * \\
(3.00)\end{array}$ & $\begin{array}{l}-0.054 \\
(-0.54)\end{array}$ \\
\hline Foreign Banks Share & $\begin{array}{l}-0.047 \\
(-0.72)\end{array}$ & $\begin{array}{l}-0.053 \\
(-0.70)\end{array}$ & $\begin{array}{l}0.050 \\
(1.30)\end{array}$ & $\begin{array}{l}0.040 \\
(1.32)\end{array}$ & $\begin{array}{c}0.126^{*} \\
(2.18)\end{array}$ & $\begin{array}{l}0.116 \\
(1.81)\end{array}$ & $\begin{array}{c}0.171 * * * \\
(6.38)\end{array}$ & $\begin{array}{l}-0.049 \\
(-0.63)\end{array}$ \\
\hline State Banks Share & $\begin{array}{l}-0.056 \\
(-0.92)\end{array}$ & $\begin{array}{l}-0.095 \\
(-1.20)\end{array}$ & $\begin{array}{l}0.011 \\
(0.28)\end{array}$ & $\begin{array}{c}0.064 * \\
(1.84)\end{array}$ & $\begin{array}{c}0.432 * * * \\
(4.12)\end{array}$ & $\begin{array}{c}0.402 * * \\
(2.87)\end{array}$ & $\begin{array}{c}0.385^{* *} * \\
(3.23)\end{array}$ & $\begin{array}{l}-0.058 \\
(-0.43)\end{array}$ \\
\hline Inflation & $\begin{array}{l}-0.051 \\
(-0.68)\end{array}$ & $\begin{array}{l}-0.071 \\
(-0.84)\end{array}$ & $\begin{array}{l}0.064 \\
(1.02)\end{array}$ & $\begin{array}{l}-0.003 \\
(-0.05)\end{array}$ & $\begin{array}{l}-0.106 \\
(-0.96)\end{array}$ & $\begin{array}{l}-0.093 \\
(-0.71)\end{array}$ & $\begin{array}{l}-0.015 \\
(-0.51)\end{array}$ & $\begin{array}{l}-0.027 \\
(-0.30)\end{array}$ \\
\hline Per Capita & $\begin{array}{c}-2.000 * * \\
(-2.64)\end{array}$ & $\begin{array}{c}-2.106^{*} \\
(-2.07)\end{array}$ & $\begin{array}{c}3.793 * * * \\
(3.94)\end{array}$ & $\begin{array}{c}3.391 * * \\
(2.84)\end{array}$ & $\begin{array}{l}-0.525 \\
(-1.80)\end{array}$ & $\begin{array}{l}-0.391 \\
(-0.92)\end{array}$ & $\begin{array}{c}-1.032 * * \\
(-2.45)\end{array}$ & $\begin{array}{l}0.922 \\
(1.20)\end{array}$ \\
\hline Remittance Inflow & $\begin{array}{l}-0.261 \\
(-0.69)\end{array}$ & $\begin{array}{l}-0.195 \\
(-0.38)\end{array}$ & $\begin{array}{l}0.221 \\
(1.12)\end{array}$ & $\begin{array}{l}0.035 \\
(0.26)\end{array}$ & $\begin{array}{c}-0.816^{* *} \\
(-2.32)\end{array}$ & $\begin{array}{c}-0.808 * \\
(-2.22)\end{array}$ & $\begin{array}{l}0.223 \\
(0.22)\end{array}$ & $\begin{array}{l}0.664 \\
(1.13)\end{array}$ \\
\hline Trend & $\begin{array}{c}1.544 * * * \\
(4.47)\end{array}$ & $\begin{array}{c}1.516 * * * \\
(4.23)\end{array}$ & $\begin{array}{c}0.370^{* *} \\
(3.29)\end{array}$ & $\begin{array}{c}-0.402 * * \\
(-2.87)\end{array}$ & $\begin{array}{l}0.939 \\
(1.17)\end{array}$ & $\begin{array}{l}0.908 \\
(1.11)\end{array}$ & $\begin{array}{l}1.459 \\
(1.35)\end{array}$ & $\begin{array}{l}-1.730 \\
(-1.25)\end{array}$ \\
\hline Constant & $44.794 * * *$ & $48.327 * * *$ & 1.555 & $-16.412 * *$ & $28.775 * * *$ & $31.331 * * *$ & 9.825 & 10.399 \\
\hline
\end{tabular}




\begin{tabular}{|c|c|c|c|c|c|c|c|c|}
\hline & $(8.23)$ & $(6.53)$ & $(0.27)$ & $(-2.32)$ & (5.33) & (7.00) & $(0.68)$ & $(0.90)$ \\
\hline Observations & 71 & 68 & 68 & 73 & 37 & 36 & 39 & 40 \\
\hline R-squared & 0.669 & 0.608 & 0.754 & 0.361 & 0.777 & 0.769 & 0.571 & 0.397 \\
\hline Number of Country & 9 & 9 & 9 & 10 & 10 & 10 & 10 & 10 \\
\hline
\end{tabular}




\section{References}

Abdelsalam, O., Fethi, M.D., Matallin, J.C., Tortosa-Ausina, E., 2014. On the comparative performance of socially responsible and Islamic mutual funds.Journal of Economic Behavior \& Organization103, S108-S128.

Abedifar, P., Ebrahim, M.S., Molyneux, P., Tarazi, A., 2015. Islamic banking and finance: Recent empirical literature and directions for future research.Journal of Economic Surveys29, 637-670.

Abedifar, P., Molyneux, P., Tarazi, A., 2013. Risk in Islamic banking.Review of Finance17, 2035-2096.

Aggarwal, R.K., Yousef, T.,2000. Islamic banks and investment financing.Journal of Money, Credit and Banking32, 93-120.

Alessandri, P., Drehmann, M., 2010. An economic capital model integrating credit and interest rate risk in the banking book.Journal of Banking \& Finance34, 730-742.

Armendariz de Aghion, B., Morduch, J., 2005. The economics of microfinance.Cambridge, MA: MIT Press.

Ayyagari, M., Demirguc-Kunt, A., Maksimovic, M., 2008. How important are financing constraints? The role of finance in the business environment.World Bank Economic Review22, 483-516.

Baele, L., Farooq, M., Ongena, S., 2014. Of religion and redemption: Evidence from default on Islamic loans.Journal of Banking \& Finance44, 141-159.

Beck T., Demirgüç-Kunt, A., Levine, R., 2007. Finance, inequality and the poor.Journal of Economic Growth12, 27-49.

Beck T., Demirgüç-Kunt, A., Merrouche, O., 2013. Islamic vs. conventional banking: business model, efficiency and stability.Journal of Banking \& Finance37, 433-447.

Beck, T., Levine, R., 2004. Stock markets, banks, and growth: Panel evidence.Journal of Banking \& Finance28, 423-442.

Beck, T., Levine, R., Loayza, N.,2000. Finance and the Source of Growth.Journal of Financial Economics58, 261-300.

Berger, A.N., De Young, R., 1997. Problem loans and cost efficiency in commercial banking.Journal of Banking and Finance21, 849-870.

Berger, A.N., Hasan, I., Klapper, L.F., 2004. Further evidence on the link between finance and growth: An international analysis of community banking and economic performance.Journal of Financial Services Research25, 169-202.

Berger, A.N., Herring, R.J., Szegö, G.P.,1995. The role of capital in financial institutions.Journal of Banking \& Finance19, 257-276.

Berger, A.N., Udell, G., 2004. The institutional memory hypothesis and the procyclicality of bank lending behaviour.Journal of Financial Intermediation13, 458-495. 
Borio, C., Zhu, H., 2008. Capital regulation, risk-taking and monetary policy: A missing link in the transmission mechanism? Bank for International Settlements Working Paper No. 268.

Buffie, E.F.,1984. Financial repression, the new structuralists, and stabilization policy in semiindustrialized economies.Journal of Development Economics14, 305-322.

Burgess, R., Pande, R.,2005. Can rural banks reduce poverty? Evidence from the Indian social banking experiment.American Economic Review95, 780-795.

Carbó Valverde, S.,Rodríguez Fernández, F., 2007. The determinants of bank margins in European banking.Journal of Banking \& Finance31, 2043-2063.

Carling, K., Jacobson, T., Linde, J., Roszbach, K., 2007. Corporate credit risk modeling and the macroeconomy. Journal of Banking \& Finance31, 845-868.

C.G.A.P., 2008. Islamic microfinance: An emerging market niche, No. 49, August.

Chandavarkar, A., 1992. Of finance and development: neglected and unsettled questions. World Development20, 133-142.

Christopoulos, D.K., Tsionas, E.G., 2004. Financial Development and Economic Growth: Evidence from Panel Unit Root and Cointegration Tests.Journal of Development Economics73, 55-74.

Chong, B.S., Liu, M.H., 2009. Islamic banking: Interest-free or interest-based?Journal of PacificBasin Finance17, 125-144.

Čihák, M., Hesse, H., 2010. Islamic banks and financial stability: An empirical analysis.Journal of Financial Services Research38, 95-113.

Delis, M.D., Kouretas, G.P., 2011. Interest rates and bank risk-taking.Journal of Banking \& Finance35, 840-855.

Dell'Ariccia, G., Marquez, R., 2006. Lending booms and lending standards.The Journal of Finance61, 2511-2546.

Demsetz, H., 1973. Industry structure, market rivalry, and public policy.Journal of Law and Economics16, 1 -9.

Drehmann, M., Sorensen, S., Stringa, M., 2010. The integrated impact of credit and interest rate risk on banks: A dynamic framework and stress testing application.Journal of Banking \& Finance34, 735-751.

Ebrahim, M.S., 2009. Can an Islamic model of housing finance cooperative elevate the economic status of the underprivileged?Journal of Economic Behavior \& Organization72, 864-883.

Elnahass, M., Izzeldin, M., Abdelsalam, O., 2014.Loan loss provisions, bank valuations and discretion: A comparative study between conventional and Islamic banks.Journal of Economic Behavior \& Organization103, S160-S173.

Ernst \& Young,2013-2014. World Islamic Banking Competitiveness Report.

Fiordelisi, F., Marques-Ibanez, D., Molyneux, P., 2011. Efficiency and risk in European banking.Journal of Banking \& Finance35, 1315-1326. 
Frankfurt School of Finance and Management (Bankakademie International), 2006. Access to Finance Study in Algeria, Final Report. Frankfurt: Frankfurt School of Finance and Management, July.

Fry, M.J.,1988. Money, Interest, and Banking in Economic Development. Baltimore, MD, and London: Johns Hopkins University Press.

Gheeraert, L., 2014. Does Islamic finance spur banking sector development? Journal of Economic Behavior \& Organization 103, S4-S20.

Gheeraert, L., Weill, L., 2014. Does Islamic banking development favour macroeconomic efficiency? Evidence on the Islamic finance-growth nexus. Laboratoire de Recherche en Gestion \& Economie Working Paper 2014-04.

Gonzalez, F., 2005. Bank regulation and risk taking incentives: An international comparison of bank risk.Journal of Banking \& Finance29, 1153-1184.

Harris, M., Raviv, A.,1990. Capital structure and the informational role of debt.Journal of Finance45, 321-349.

Hicks, J.,1935. Annual survey of economic theory: The theory of monopoly.Econometrica3, 120.

Hilary, G., Hui, K. W., 2009. Does religion matter in corporate decision making in America?Journal of Financial Economics93, 455-473.

Hofstede, G.H., 2001. Culture's Consequences: Comparing Values, Behaviors, Institutions, and Organizations across Nations.Thousand Oaks, CA:SAGE Publications.

Honohan, P.,2004. Financial Development, Growth and Poverty: How close are the links? In: C. Goodhart (Ed.), Financial Development and Economic Growth: Explaining the links, 1-37, London: Palgrave.

Honohan, P., 2008. Cross-country variation in household access to financial services.Journal of Banking \& Finance32, 2493-2500.

Hughes, J.P., Mester, L., Moon, C., 2001. Are scale economies in banking elusive or illusive: Evidence obtained by incorporating capital structure and risk-taking into models of bank production.Journal of Banking \& Finance25, 2169-2208.

Jarrow, R.A., Turnbull, S.M., 2000. The intersection of market and credit risk.Journal of Banking \& Finance24, 271-299.

Jensen, M. C.,1986. Agency costs of free cash flow, corporate finance and takeovers.American Economic Review76, 323-29.

Jiménez, G., Lopez, J., Saurina, J., 2013. How does competition affect bank risk taking? Journal of Financial Stability9, 185-195.

Jobst, A.A., 2007. The Economics of Islamic Finance and Securitization.Journal of Structured Finance13, 6-27.

Johnes, J., Izzeldin, M., Pappas, V., 2014. A comparison of performance of Islamic and conventional banks 2004-2009.Journal of Economic Behavior \& Organization103, S93S107. 
Kane, E., 2010. Redefining and containing systemic risk.Atlantic Economic Journal38, 251-264.

Koetter, M., Noth, F., 2013. IT use, productivity, and market power in banking.Journal of Financial Stability9, 695-704.

Kwan, S., Eisenbeis, R., 1997.Bank risk, capitalization and operating efficiency.Journal of Financial Services Research12, 117-31.

Levine, R., 1997. Financial Development and Economic Growth: Views and Agenda.Journal of Economic Literature35, 688-726.

Levine, R., 2005. Finance and Growth: Theory and Evidence. In P. Aghion and S. Durlaff (Eds.),Handbook of Economic Growth, 866-934. The Netherlands: Elsevier Science.

Levine, R., Loayza, N., Beck, T., 2000. Financial Intermediation and Growth: Causality and Causes.Journal of Monetary Economics46, 31-77.

Maddaloni, A., Peydró, J., 2011. Bank risk-taking, securitization, supervision, and low interest rates: Evidence from the Euro area and U.S. lending standards.Review of Financial Studies24, 2121-65.

Maudos, J., De Guevara, J.F., 2004. Factors explaining the interest margin in the banking sectors of the European Union.Journal of Banking \& Finance28, 2259-2281.

McShane, R.W., Sharpe, I.G.,1985. A time series/cross section analysis of the determinants of Australian trading bank loan/deposit interest margins: 1962-1981.Journal of Banking \& Finance9, 115-136.

Merton, R.C., Bodie, Z., 2004. The design of financial systems: towards a synthesis of function and structure.Journal of Investment Management3, 1-23.

Miller, A., Hoffmann, J., 1995. Risk and religion: An explanation of gender differences in religiosity.Journal for the Scientific Study of Religion34, 63-75.

Ongena, S.,Şendeniz-Yüncü, İ., 2011.Which firms engage small, foreign, or state banks? And who goes Islamic? Evidence from Turkey.Journal of Banking \& Finance 35, 3213-3224.

Osoba, B., 2003. Risk preferences and the practice of religion: Evidence from panel data. Unpublished Working Paper, West Virginia University.

Pew Research Center, 2009. Mapping the global Muslim population: a report on the size and distribution of the World's Muslim population.The Pew Forum on Religion \& Public Life, October 2009.

Rajan, R.G., 2006. Has finance made the world riskier? European Financial Management12, 499-533.

Rioja, F., Valev, N., 2004. Does one size fit all?: a reexamination of the finance and growth relationship.Journal of Development Economics74, 429-447.

Rousseau, P.L., Sylla, R., 1999. Emerging Financial Markets and Early US Growth.National Bureau of Economic Research Working Paper No. 7448.

Rousseau, P.L., Wachtel, P., 2002. Inflation thresholds and the finance-growth nexus.Journal of International Money and Finance21, 777-793. 
Saeed, M., Izzeldin, M., 2014. Examining the relationship between default risk and efficiency in Islamic and conventional banks.Journal of Economic Behavior \& Organization.

Taylor, L., 1983. Structuralist Macroeconomics: Applicable Models for the Third World. New York: Basic Books.

The Banker, 2013. Islamic finance in 2013: Beyond the growth, March.

van Wijnbergen, S.,1983. Interest rate management in LDCs. Journal of Monetary Economics12, 433-452. 


\section{Table 1. Descriptive Statistics}

This table presents the descriptive statistics for 22 countries where commercial Islamic and conventional banks both operated for the 1999-2011 period. We split the sample into two parts on the basis of the median value of the proportion of Muslims in the population.

\begin{tabular}{|c|c|c|c|c|c|c|c|c|c|c|c|}
\hline \multirow[b]{2}{*}{ Variables } & \multicolumn{5}{|c|}{$\begin{array}{l}\text { Countries with Muslim percentage of populations } \\
\text { below the median }(95 \%)\end{array}$} & \multicolumn{5}{|c|}{$\begin{array}{l}\text { Countries with Muslim percentage of } \\
\text { populations above the median }(95 \%)\end{array}$} & \multirow[b]{2}{*}{ T-Stat. $\dagger$} \\
\hline & Obs & Mean & S.D. & Min & Max & Obs & Mean & S.D & Min & Max & \\
\hline \multicolumn{12}{|l|}{ Banking System Structure } \\
\hline Small ISB Share & 128 & 18.54 & 35.45 & 0.00 & 100.00 & 143 & 10.68 & 25.89 & 0.00 & 100.00 & $2.07 * *$ \\
\hline Medium ISB Share & 128 & 25.48 & 28.97 & 0.00 & 100.00 & 143 & 20.00 & 22.44 & 0.00 & 83.52 & $1.73 *$ \\
\hline Large ISB Share & 128 & 21.13 & 26.95 & 0.00 & 100.00 & 143 & 8.20 & 19.72 & 0.00 & 100.00 & $4.46^{* * *}$ \\
\hline Small ISW Share & 128 & 4.68 & 15.37 & 0.00 & 100.00 & 143 & 7.40 & 23.26 & 0.00 & 100.00 & -1.15 \\
\hline Medium ISW Share & 128 & 10.04 & 13.66 & 0.00 & 53.33 & 143 & 8.38 & 21.15 & 0.00 & 100.00 & 0.78 \\
\hline Large ISW Share & 128 & 14.02 & 15.78 & 0.00 & 71.66 & 143 & 13.01 & 26.83 & 0.00 & 100.00 & 0.38 \\
\hline Foreign Banks Share & 130 & 19.45 & 19.25 & 0.00 & 92.75 & 136 & 29.95 & 28.17 & 0.00 & 97.23 & $-3.56 * * *$ \\
\hline State Banks Share & 130 & 17.23 & 24.72 & 0.00 & 100.00 & 136 & 16.16 & 23.84 & 0.00 & 98.41 & 0.36 \\
\hline HHI & 110 & 21.94 & 14.57 & 6.19 & 86.17 & 114 & 27.99 & 13.89 & 9.51 & 58.69 & $-3.18 * * *$ \\
\hline \multicolumn{12}{|c|}{ Funding Mobilization and Allocation } \\
\hline Bank Deposit & 99 & 64.88 & 27.86 & 25.07 & 139.38 & 130 & 35.19 & 22.17 & 6.98 & 105.91 & $8.71 * * *$ \\
\hline Financial System Deposit & 87 & 64.60 & 25.55 & 25.07 & 120.93 & 121 & 36.96 & 22.17 & 8.92 & 105.91 & $8.13^{* * *}$ \\
\hline Private Credit & 91 & 50.81 & 30.50 & 9.66 & 142.85 & 124 & 28.09 & 20.77 & 3.39 & 81.85 & $6.14 * * *$ \\
\hline \multicolumn{12}{|c|}{ Economic Growth, Income Inequality \& Poverty Index } \\
\hline Economic Growth & 130 & 1.65 & 4.19 & -11.99 & 14.18 & 136 & 1.81 & 3.58 & -17.06 & 15.73 & -0.34 \\
\hline Gini & 16 & 35.50 & 5.22 & 28.99 & 46.21 & 31 & 37.91 & 4.59 & 29.63 & 47.28 & -1.56 \\
\hline Poverty Ratio International & 19 & 20.45 & 18.90 & 0.00 & 58.59 & 31 & 12.84 & 14.14 & 0.00 & 44.19 & 1.51 \\
\hline Poverty Ratio National & 21 & 18.98 & 10.83 & 3.60 & 48.90 & 30 & 26.85 & 14.03 & 2.80 & 55.20 & $-2.26^{* *}$ \\
\hline Poverty Gap International & 19 & 5.00 & 5.47 & 0.00 & 18.61 & 31 & 3.37 & 4.20 & 0.00 & 14.34 & 1.12 \\
\hline Poverty Ratio Rural & 21 & 23.24 & 10.88 & 7.10 & 52.30 & 24 & 38.28 & 17.00 & 6.80 & 73.90 & $-3.58 * * *$ \\
\hline \multicolumn{12}{|c|}{ Other Country Level Heterogeneities } \\
\hline Muslim Share & 130 & 78.22 & 13.48 & 51.90 & 94.70 & 136 & 97.88 & 1.46 & 95.3 & 99.8 & $-16.54 * * *$ \\
\hline Per Capita & 130 & 28.05 & 28.06 & 0.93 & 133.73 & 136 & 6.67 & 7.47 & 1.51 & 49.23 & $8.41 * * *$ \\
\hline Uncertainty Avoidance Index & 128 & 59.66 & 12.44 & 36.00 & 68.00 & 143 & 65.91 & 8.73 & 54.00 & 85.00 & $-4.74 * * *$ \\
\hline Economic Freedom Index & 121 & 61.22 & 8.77 & 44.30 & 77.90 & 143 & 54.65 & 11.73 & 16.80 & 65.90 & $5.20 * * *$ \\
\hline Inflation & 130 & 7.49 & 8.16 & -24.25 & 29.02 & 136 & 8.99 & 11.23 & -30.14 & 54.18 & -1.25 \\
\hline Remittance Inflow & 67 & 6.06 & 7.27 & 0.33 & 25.66 & 114 & 6.04 & 6.13 & 0.00 & 22.40 & 0.03 \\
\hline \multicolumn{12}{|c|}{ Conventional Banks Characteristics } \\
\hline Total Assets (\$ m) & 1917 & 4,344 & 8,980 & 6 & 83,000 & 1047 & 5,981 & 13,200 & 0.09 & 98,700 & $-3.59 * * *$ \\
\hline Inefficiency & 1917 & 13.32 & 10.32 & 0.71 & 63.23 & 1047 & 14.22 & 11.60 & 0.71 & 63.23 & $-2.10 * *$ \\
\hline Capital & 1714 & 53.69 & 27.34 & 6.17 & 177.45 & 901 & 60.56 & 31.39 & 6.17 & 177.45 & $-5.56 * * *$ \\
\hline Credit Risk & 1345 & 10.02 & 12.37 & 0.00 & 72.19 & 626 & 12.17 & 14.57 & 0.00 & 72.19 & $-3.19 * * *$ \\
\hline
\end{tabular}

${ }^{\dagger}$ T-Stat. of mean equality test. $* * *, * *$, and $*$ indicate significance at $1 \%, 5 \%$, and $10 \%$ respectively. See table A1 for variable definitions. 


\section{Table 2.Islamic Banking in Predominantly Muslim Countries}

This table illustrates the estimation of the equation (1) for the sample of Predominantly Muslim Countries:

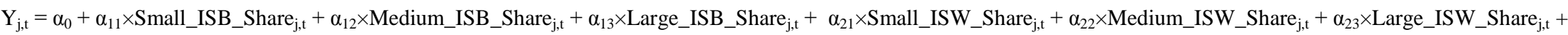
$\alpha_{3} \times$ Foreign_Banks_Share $\mathrm{j}_{\mathrm{j}, \mathrm{t}}+\alpha_{4} \times$ State_Banks_Share $\mathrm{j}_{\mathrm{j}, \mathrm{t}}+\alpha_{5} \times$ Inflation $_{\mathrm{j}, \mathrm{t}}+\alpha_{6} \times$ Per_Capita $_{\mathrm{j}, \mathrm{t}}+\alpha_{7} \times$ Remittance_Inflow $_{\mathrm{j}, \mathrm{t}}+\alpha_{8} \times \operatorname{Trend}_{\mathrm{t}}+\varepsilon_{\mathrm{j}, \mathrm{t}}$

We split our sample into two groups on the basis of the median proportion of Muslims in a country's population. Countries above the median value are classified in one group (PredominantlyMuslim Countries). The median value is $95 \%$.

We regress our dependent variables on our variable of interest (i.e., Small ISB Share, MediumISB Shareand Large ISB Share) and control variables. In columns (1) to (3), we study the relationship between our variables of interest and development of financial intermediation. Columns (4) to (9) present our analysis for economic growth, income inequality and poverty index.

We employ the fixed-effect technique for our estimation. Standard errors are clustered at the country level. Robust z-statistics are reported in parentheses. $* * *$, $* *$, and $*$ indicate significance at $1 \%, 5 \%$, and $10 \%$ respectively. See table A1 for variable definitions.

\begin{tabular}{|c|c|c|c|c|c|c|c|c|c|}
\hline & \multicolumn{3}{|c|}{ Funding Mobilization and Allocation } & \multicolumn{6}{|c|}{ Economic Growth, Income Inequality and Poverty Index } \\
\hline & Bank Deposit & Financial System Deposit & Private Credit & Economic Growth & Gini & Poverty Ratio International & Poverty Ratio National & Poverty Gap International & Poverty Ratio Rural \\
\hline Variables & (1) & (2) & (3) & (4) & (5) & (6) & (7) & (8) & (9) \\
\hline Small ISB Share & $\begin{array}{l}0.009 \\
(0.38)\end{array}$ & $\begin{array}{l}-0.003 \\
(-0.12)\end{array}$ & $\begin{array}{l}-0.018 \\
(-0.71)\end{array}$ & $\begin{array}{l}-0.026 \\
(-0.99)\end{array}$ & $\begin{array}{l}2.606 \\
(0.29)\end{array}$ & $\begin{array}{l}-6.921 \\
(-0.28)\end{array}$ & $\begin{array}{c}69.527 * * * * \\
(12.80)\end{array}$ & $\begin{array}{l}-4.377 \\
(-0.58)\end{array}$ & --- \\
\hline Medium ISB Share & $\begin{array}{c}0.040 * * \\
(2.56)\end{array}$ & $\begin{array}{c}0.040 * * \\
(2.65)\end{array}$ & $\begin{array}{c}0.066 * * \\
(2.42)\end{array}$ & $\begin{array}{l}0.016 \\
(0.55)\end{array}$ & $\begin{array}{c}-0.064 * * \\
(-3.20)\end{array}$ & $\begin{array}{l}-0.036 \\
(-0.42)\end{array}$ & $\begin{array}{c}-0.131 * * * \\
(-3.50)\end{array}$ & $\begin{array}{l}-0.012 \\
(-0.44)\end{array}$ & $\begin{array}{c}-0.044 * * * \\
(-4.74)\end{array}$ \\
\hline Large ISB Share & $\begin{array}{l}0.032 \\
(1.10)\end{array}$ & $\begin{array}{l}0.004 \\
(0.16)\end{array}$ & $\begin{array}{l}0.024 \\
(1.00)\end{array}$ & $\begin{array}{l}-0.022 \\
(-1.55)\end{array}$ & $\begin{array}{l}-0.037 \\
(-0.57)\end{array}$ & $\begin{array}{l}0.057 \\
(0.42)\end{array}$ & $\begin{array}{c}-0.303 * * * \\
(-5.13)\end{array}$ & $\begin{array}{l}0.027 \\
(0.68)\end{array}$ & $\begin{array}{c}1.202 * * \\
(3.09)\end{array}$ \\
\hline Small ISW Share & $\begin{array}{l}-0.005 \\
(-0.28)\end{array}$ & $\begin{array}{l}0.003 \\
(0.20)\end{array}$ & $\begin{array}{l}0.001 \\
(0.06)\end{array}$ & $\begin{array}{l}0.033 * \\
(2.14)\end{array}$ & $\begin{array}{c}0.051^{* * * *} \\
(4.77)\end{array}$ & $\begin{array}{l}-0.030 \\
(-1.09)\end{array}$ & $\begin{array}{c}-0.438^{* * * *} \\
(-13.00)\end{array}$ & $\begin{array}{l}-0.006 \\
(-0.75)\end{array}$ & $\begin{array}{c}-0.670 * * * \\
(-22.36)\end{array}$ \\
\hline Medium ISW Share & $\begin{array}{l}0.022 \\
(0.64)\end{array}$ & $\begin{array}{l}0.036 \\
(0.97)\end{array}$ & $\begin{array}{l}0.066 \\
(0.74)\end{array}$ & $\begin{array}{l}0.037 \\
(1.06)\end{array}$ & $\begin{array}{l}-0.017 \\
(-0.39)\end{array}$ & $\begin{array}{l}-0.045 \\
(-0.39)\end{array}$ & $\begin{array}{c}-0.975^{* * * *} \\
(-8.87)\end{array}$ & $\begin{array}{l}-0.010 \\
(-0.29)\end{array}$ & $\begin{array}{c}-2.038 * * * \\
(-8.02)\end{array}$ \\
\hline Large ISW Share & $\begin{array}{c}0.169 * * * \\
(3.97)\end{array}$ & $\begin{array}{c}0.169 * * * \\
(3.63)\end{array}$ & $\begin{array}{c}0.138 * * * \\
(3.34)\end{array}$ & $\begin{array}{l}-0.030 \\
(-1.27)\end{array}$ & $\begin{array}{c}-0.064 * * * \\
(-5.39)\end{array}$ & $\begin{array}{c}0.158^{* * * *} \\
(10.62)\end{array}$ & $\begin{array}{c}0.874 * * * \\
(7.88)\end{array}$ & $\begin{array}{c}0.029 * * * * \\
(6.26)\end{array}$ & $\begin{array}{c}4.422 * * * \\
(5.32)\end{array}$ \\
\hline Foreign Banks Share & $\begin{array}{l}-0.008 \\
(-0.16)\end{array}$ & $\begin{array}{l}-0.012 \\
(-0.19)\end{array}$ & $\begin{array}{l}0.030 \\
(0.63)\end{array}$ & $\begin{array}{l}-0.018 \\
(-0.50)\end{array}$ & $\begin{array}{l}-0.023 \\
(-0.27)\end{array}$ & $\begin{array}{l}-0.064 \\
(-0.23)\end{array}$ & $\begin{array}{c}0.302 * * \\
(2.53)\end{array}$ & $\begin{array}{l}-0.040 \\
(-0.47)\end{array}$ & $\begin{array}{c}0.254 * * * \\
(26.39)\end{array}$ \\
\hline State Banks Share & $\begin{array}{l}-0.052 \\
(-1.10)\end{array}$ & $\begin{array}{l}-0.076 \\
(-1.21)\end{array}$ & $\begin{array}{l}-0.017 \\
(-0.25)\end{array}$ & $\begin{array}{l}-0.040 \\
(-1.18)\end{array}$ & $\begin{array}{l}0.038 \\
(0.38)\end{array}$ & $\begin{array}{l}0.027 \\
(0.20)\end{array}$ & $\begin{array}{c}0.265 * * \\
(3.19)\end{array}$ & $\begin{array}{l}-0.001 \\
(-0.02)\end{array}$ & $\begin{array}{l}0.025 \\
(1.79)\end{array}$ \\
\hline Inflation & $\begin{array}{c}-0.161^{*} \\
(-2.10)\end{array}$ & $\begin{array}{c}-0.164 * \\
(-2.06)\end{array}$ & $\begin{array}{c}-0.166 \text { **** } \\
(-3.36)\end{array}$ & $\begin{array}{l}-0.042 \\
(-0.86)\end{array}$ & $\begin{array}{l}0.020 \\
(1.05)\end{array}$ & $\begin{array}{l}-0.060 \\
(-1.22)\end{array}$ & $\begin{array}{c}0.071 * * \\
(2.51)\end{array}$ & $\begin{array}{l}-0.021 \\
(-1.52)\end{array}$ & $\begin{array}{c}-0.201 * * * \\
(-84.73)\end{array}$ \\
\hline Per Capita & $\begin{array}{l}0.217 \\
(1.04)\end{array}$ & $\begin{array}{l}0.283 \\
(1.36)\end{array}$ & $\begin{array}{l}0.299 \\
(0.68)\end{array}$ & $\begin{array}{c}0.488^{* * *} \\
(3.21)\end{array}$ & $\begin{array}{l}-0.163 \\
(-0.63)\end{array}$ & $\begin{array}{l}0.194 \\
(1.01)\end{array}$ & $\begin{array}{c}-3.356 * * * \\
(-16.10)\end{array}$ & $\begin{array}{l}0.036 \\
(0.65)\end{array}$ & $\begin{array}{c}-5.865 * * * \\
(-189.59)\end{array}$ \\
\hline Remittance Inflow & $\begin{array}{l}0.357 \\
(1.17)\end{array}$ & $\begin{array}{l}0.506 \\
(1.73)\end{array}$ & $\begin{array}{l}0.664 \\
(1.56)\end{array}$ & $\begin{array}{l}0.141 \\
(1.79)\end{array}$ & $\begin{array}{c}0.440 * * \\
(2.95)\end{array}$ & $\begin{array}{l}-0.007 \\
(-0.01)\end{array}$ & $\begin{array}{c}-2.678 * * * * \\
(-6.94)\end{array}$ & $\begin{array}{l}-0.056 \\
(-0.27)\end{array}$ & $\begin{array}{c}-3.237 * * * * \\
(-7.75)\end{array}$ \\
\hline Trend & $\begin{array}{c}1.016 * * * \\
(6.99)\end{array}$ & $\begin{array}{c}0.967 * * * \\
(6.43)\end{array}$ & $\begin{array}{c}0.765 * * * \\
(4.28)\end{array}$ & $\begin{array}{c}-0.276 * * * \\
(-4.88)\end{array}$ & $\begin{array}{l}-0.295 \\
(-1.26)\end{array}$ & $\begin{array}{c}-0.577 * * * * \\
(-3.82)\end{array}$ & $\begin{array}{l}0.250 \\
(1.30)\end{array}$ & $\begin{array}{c}-0.151 * * * \\
(-3.71)\end{array}$ & $\begin{array}{c}0.718^{* * * *} \\
(4.35)\end{array}$ \\
\hline Constant & $\begin{array}{c}28.011 * * * \\
(8.61)\end{array}$ & $\begin{array}{c}28.853 * * * \\
(7.82)\end{array}$ & $\begin{array}{c}15.228^{* *} \\
(2.38)\end{array}$ & $\begin{array}{l}1.287 \\
(0.54)\end{array}$ & $\begin{array}{c}40.364 * * * \\
(11.62)\end{array}$ & $\begin{array}{l}15.382 \\
(1.12)\end{array}$ & $\begin{array}{c}47.887 * * * \\
(8.10)\end{array}$ & $\begin{array}{l}5.430 \\
(1.30)\end{array}$ & $\begin{array}{c}33.752 * * \\
(2.70)\end{array}$ \\
\hline Observations & 108 & 104 & 107 & 113 & 28 & 28 & 27 & 28 & 22 \\
\hline R-squared & 0.635 & 0.619 & 0.578 & 0.182 & 0.845 & 0.752 & 0.987 & 0.732 & 0.984 \\
\hline Number of Country & 10 & 10 & 10 & 10 & 8 & 8 & 8 & 8 & 7 \\
\hline
\end{tabular}


Table 3. Islamic Banking in Low Income Countries

This table illustrates the estimation of the equation (1) for the sample of Low Income Countries:

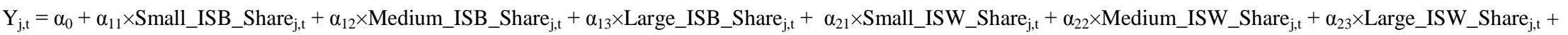
$\alpha_{3} \times$ Foreign_Banks_Share $_{j, \mathrm{t}}+\alpha_{4} \times$ State_Banks_Share $_{\mathrm{j}, \mathrm{t}}+\alpha_{5} \times$ Inflation $_{\mathrm{j}, \mathrm{t}}+\alpha_{6} \times$ Per_Capita $_{\mathrm{j}, \mathrm{t}}+\alpha_{7} \times$ Remittance_Inflow $_{\mathrm{j}, \mathrm{t}}+\alpha_{8} \times \operatorname{Trend}_{\mathrm{t}}+\varepsilon_{\mathrm{j}, \mathrm{t}}$

We split our sample into two groups on the basis of the median value of countries' Per Capita. Countries below the median value are classified in one group (called Low Income Countries). The median value is about $\$ 6,300$.

We regress our dependent variables on our variable of interest (i.e., Small ISB Share, Medium ISB Share and Large ISB Share) and control variables. In columns (1) to (3), we study the relationship between our variables of interest and development of financial intermediation. Columns (4) to (9) present our analysis for economic growth, income inequality and poverty index.

We employ the fixed-effect technique for our estimation. Standard errors are clustered at the country level. Robust z-statistics are reported in parentheses. $* * *$, $* *$, and $*$ indicate significance at $1 \%, 5 \%$, and $10 \%$ respectively. See table A1 for variable definitions.

\begin{tabular}{|c|c|c|c|c|c|c|c|c|c|}
\hline & \multicolumn{3}{|c|}{ Funding Mobilization and Allocation } & \multicolumn{6}{|c|}{ Economic Growth, Income Inequality and Poverty Index } \\
\hline & Bank Deposit & Financial System Deposit & Private Credit & Economic Growth & Gini & Poverty Ratio International & Poverty Ratio National & Poverty Gap International & Poverty Ratio Rural \\
\hline Variables & (1) & (2) & (3) & (4) & (5) & (6) & (7) & (8) & (9) \\
\hline Small ISB Share & $\begin{array}{l}-0.006 \\
(-0.25)\end{array}$ & $\begin{array}{l}-0.007 \\
(-0.26)\end{array}$ & $\begin{array}{l}0.036 \\
(1.14)\end{array}$ & $\begin{array}{l}-0.011 \\
(-0.52)\end{array}$ & $\begin{array}{l}0.051 \\
(1.39)\end{array}$ & $\begin{array}{l}-0.069 \\
(-1.18)\end{array}$ & $\begin{array}{l}-0.105 \\
(-1.13)\end{array}$ & $\begin{array}{l}-0.033 \\
(-1.14)\end{array}$ & $\begin{array}{l}-0.129 \\
(-1.16)\end{array}$ \\
\hline Medium ISB Share & $\begin{array}{c}0.073^{* *} \\
(2.69)\end{array}$ & $\begin{array}{l}0.072^{*} \\
(2.14)\end{array}$ & $\begin{array}{l}0.095 \\
(1.76)\end{array}$ & $\begin{array}{c}0.042 * * * \\
(3.38)\end{array}$ & $\begin{array}{l}0.052 \\
(0.94)\end{array}$ & $\begin{array}{c}-0.177 * * * * \\
(-3.49)\end{array}$ & $\begin{array}{l}-0.096 \\
(-1.73)\end{array}$ & $\begin{array}{c}-0.052^{* * *} \\
(-3.06)\end{array}$ & $\begin{array}{c}-0.190^{*} \\
(-2.20)\end{array}$ \\
\hline Large ISB Share & $\begin{array}{l}0.058 \\
(1.43)\end{array}$ & $\begin{array}{l}0.018 \\
(0.57)\end{array}$ & $\begin{array}{l}0.028 \\
(1.79)\end{array}$ & $\begin{array}{l}-0.026 \\
(-1.83)\end{array}$ & $\begin{array}{l}-0.087 \\
(-0.69)\end{array}$ & $\begin{array}{l}0.165 \\
(1.40)\end{array}$ & $\begin{array}{l}0.179 \\
(1.40)\end{array}$ & $\begin{array}{l}0.037 \\
(1.31)\end{array}$ & $\begin{array}{l}-0.171 \\
(-0.62)\end{array}$ \\
\hline Small ISW Share & $\begin{array}{l}0.017 \\
(1.24)\end{array}$ & $\begin{array}{l}0.028 \\
(1.70)\end{array}$ & $\begin{array}{c}0.053 * * \\
(2.54)\end{array}$ & $\begin{array}{l}0.003 \\
(0.21)\end{array}$ & $\begin{array}{l}0.047 * \\
(1.92)\end{array}$ & $\begin{array}{l}0.038 \\
(0.63)\end{array}$ & $\begin{array}{l}0.021 \\
(0.76)\end{array}$ & $\begin{array}{l}0.013 \\
(0.62)\end{array}$ & $\begin{array}{l}-0.024 \\
(-0.47)\end{array}$ \\
\hline Medium ISW Share & $\begin{array}{l}0.107^{*} \\
(1.86)\end{array}$ & $\begin{array}{l}0.108 \\
(1.81)\end{array}$ & $\begin{array}{l}0.073 \\
(1.81)\end{array}$ & $\begin{array}{l}0.021 \\
(1.32)\end{array}$ & $\begin{array}{l}0.068 \\
(1.15)\end{array}$ & $\begin{array}{l}-0.008 \\
(-0.16)\end{array}$ & $\begin{array}{c}0.052^{* * *} \\
(2.37)\end{array}$ & $\begin{array}{l}-0.001 \\
(-0.04)\end{array}$ & $\begin{array}{l}-0.039 \\
(-0.55)\end{array}$ \\
\hline Large ISW Share & $\begin{array}{c}0.161 * * \\
(2.94)\end{array}$ & $\begin{array}{c}0.167 * * \\
(2.91)\end{array}$ & $\begin{array}{l}0.068 \\
(1.71)\end{array}$ & $\begin{array}{l}-0.019 \\
(-0.83)\end{array}$ & $\begin{array}{l}-0.090 \\
(-1.65)\end{array}$ & $\begin{array}{c}0.127 * * \\
(2.36)\end{array}$ & $\begin{array}{l}0.144 \\
(1.63)\end{array}$ & $\begin{array}{l}0.015 \\
(0.70)\end{array}$ & $\begin{array}{l}-0.239 \\
(-0.92)\end{array}$ \\
\hline Foreign Banks Share & $\begin{array}{l}-0.127 \\
(-1.64)\end{array}$ & $\begin{array}{l}-0.137 \\
(-1.69)\end{array}$ & $\begin{array}{l}-0.106 \\
(-1.61)\end{array}$ & $\begin{array}{l}0.024 \\
(0.50)\end{array}$ & $\begin{array}{l}0.050 \\
(0.33)\end{array}$ & $\begin{array}{l}-0.185 \\
(-1.50)\end{array}$ & $\begin{array}{l}-0.082 \\
(-0.96)\end{array}$ & $\begin{array}{l}-0.045 \\
(-1.29)\end{array}$ & $\begin{array}{l}-0.075 \\
(-0.90)\end{array}$ \\
\hline State Banks Share & $\begin{array}{c}-0.242 * * \\
(-2.93)\end{array}$ & $\begin{array}{c}-0.263 * * \\
(-2.91)\end{array}$ & $\begin{array}{l}-0.052 \\
(-1.32)\end{array}$ & $\begin{array}{l}-0.006 \\
(-0.26)\end{array}$ & $\begin{array}{l}0.090 \\
(1.21)\end{array}$ & $\begin{array}{l}-0.099 \\
(-0.81)\end{array}$ & $\begin{array}{l}0.036 \\
(1.00)\end{array}$ & $\begin{array}{l}-0.013 \\
(-0.30)\end{array}$ & $\begin{array}{l}-0.014 \\
(-0.18)\end{array}$ \\
\hline Inflation & $\begin{array}{c}-0.180^{* * *} \\
(-2.50)\end{array}$ & $\begin{array}{l}-0.174 \\
(-1.53)\end{array}$ & $\begin{array}{l}-0.075 \\
(-1.20)\end{array}$ & $\begin{array}{l}0.035 \\
(1.65)\end{array}$ & $\begin{array}{c}-0.338^{*} \\
(-1.95)\end{array}$ & $\begin{array}{l}0.546^{*} \\
(1.83)\end{array}$ & $\begin{array}{l}0.232 \\
(0.86)\end{array}$ & $\begin{array}{l}0.176^{*} \\
(1.97)\end{array}$ & $\begin{array}{l}0.082 \\
(0.36)\end{array}$ \\
\hline Remittance Inflow & $\begin{array}{l}0.104 \\
(0.29)\end{array}$ & $\begin{array}{l}0.219 \\
(0.66)\end{array}$ & $\begin{array}{l}0.551 \\
(1.83)\end{array}$ & $\begin{array}{l}0.194 \\
(1.35)\end{array}$ & $\begin{array}{l}-0.045 \\
(-0.10)\end{array}$ & $\begin{array}{l}0.687 \\
(1.11)\end{array}$ & $\begin{array}{l}0.413 \\
(0.48)\end{array}$ & $\begin{array}{l}0.146 \\
(0.86)\end{array}$ & $\begin{array}{l}0.994 \\
(1.37)\end{array}$ \\
\hline Trend & $\begin{array}{l}0.588 \\
(1.53)\end{array}$ & $\begin{array}{l}0.521 \\
(1.38)\end{array}$ & $\begin{array}{l}0.180 \\
(0.48)\end{array}$ & $\begin{array}{l}-0.130 \\
(-1.24)\end{array}$ & $\begin{array}{l}0.070 \\
(0.89)\end{array}$ & $\begin{array}{c}-1.091 * * * \\
(-3.98)\end{array}$ & $\begin{array}{l}-0.265 \\
(-0.63)\end{array}$ & $\begin{array}{c}-0.363 * * * \\
(-3.28)\end{array}$ & $\begin{array}{l}-0.492 \\
(-0.96)\end{array}$ \\
\hline Constant & $\begin{array}{c}44.448 * * * \\
(7.00)\end{array}$ & $\begin{array}{c}46.199 * * * \\
(7.16)\end{array}$ & $\begin{array}{c}24.781 * * * \\
(4.77)\end{array}$ & $\begin{array}{l}0.408 \\
(0.15)\end{array}$ & $\begin{array}{c}34.169 * * * \\
(6.86)\end{array}$ & $\begin{array}{c}27.361 * * * \\
(5.19)\end{array}$ & $\begin{array}{c}22.618 * * * \\
(4.24)\end{array}$ & $\begin{array}{c}7.592 * * * \\
(5.13)\end{array}$ & $\begin{array}{c}42.316^{* * * *} \\
(4.01)\end{array}$ \\
\hline Observations & 105 & 101 & 104 & 110 & 28 & 32 & 32 & 32 & 30 \\
\hline R-squared & 0.435 & 0.413 & 0.309 & 0.168 & 0.546 & 0.761 & 0.737 & 0.750 & 0.642 \\
\hline Number of Country & 10 & 10 & 10 & 10 & 10 & 10 & 9 & 10 & 9 \\
\hline
\end{tabular}


Table 4. Islamic Banking in High Uncertainty Avoidance Countries

This table illustrates the estimation of the equation (1) for the sample of High Uncertainty Avoidance Countries:

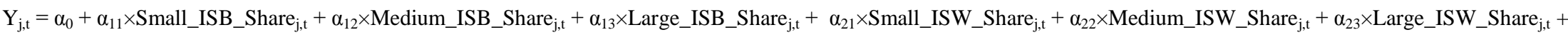
$\alpha_{3} \times$ Foreign_Banks_Share $_{\mathrm{j}, \mathrm{t}}+\alpha_{4} \times$ State_Banks_Share $_{\mathrm{j}, \mathrm{t}}+\alpha_{5} \times \operatorname{Inflation}_{\mathrm{j}, \mathrm{t}}+\alpha_{6} \times$ Per_Capita $_{\mathrm{j}, \mathrm{t}}+\alpha_{7} \times$ Remittance_Inflow $_{\mathrm{j}, \mathrm{t}}+\alpha_{8} \times \operatorname{Trend}_{\mathrm{t}}+\varepsilon_{\mathrm{j}, \mathrm{t}}$

We split our sample into two groups on the basis of the median value of countries' uncertainty avoidance index. Countries below the median value are classified in one group (called High Uncertainty Avoidance Countries). The median value is 68

We regress our dependent variables on our variable of interest (i.e., Small ISB Share, Medium ISB Share and Large ISB Share) and control variables. In columns (1) to (3), we study the relationship between our variables of interest and development of financial intermediation. Columns (4) to (9) present our analysis for economic growth, income inequality and poverty index.

We employ the fixed-effect technique for our estimation. Standard errors are clustered at the country level. Robust z-statistics are reported in parentheses. $* * *, * *$, and $*$ indicate significance at $1 \%, 5 \%$, and $10 \%$ respectively. See table A1 for variable definitions.

\begin{tabular}{|c|c|c|c|c|c|c|c|c|c|}
\hline & \multicolumn{3}{|c|}{ Funding Mobilization and Allocation } & \multicolumn{6}{|c|}{ Economic Growth, Income Inequality and Poverty Index } \\
\hline & Bank Deposit & Financial System Deposit & Private Credit & Economic Growth & Gini & Poverty Ratio International & Poverty Ratio National & Poverty Gap International & Poverty Ratio Rural \\
\hline Variables & (1) & (2) & (3) & (4) & (5) & (6) & (7) & (8) & (9) \\
\hline Small ISB Share & $\begin{array}{l}-0.019 \\
(-0.99)\end{array}$ & $\begin{array}{l}-0.029 \\
(-1.50)\end{array}$ & $\begin{array}{l}0.009 \\
(0.42)\end{array}$ & $\begin{array}{l}-0.025 \\
(-1.27)\end{array}$ & $\begin{array}{l}1.943 \\
(0.18)\end{array}$ & $\begin{array}{l}10.599 \\
(0.38)\end{array}$ & $\begin{array}{l}57.416 \\
(1.20)\end{array}$ & $\begin{array}{l}1.524 \\
(0.21)\end{array}$ & \\
\hline Medium ISB Share & $\begin{array}{l}0.072 * \\
(2.04)\end{array}$ & $\begin{array}{c}0.079^{*} \\
(1.96)\end{array}$ & $\begin{array}{c}0.097^{*} \\
(2.14)\end{array}$ & $\begin{array}{l}0.017 \\
(0.61)\end{array}$ & $\begin{array}{l}-0.032 \\
(-1.56)\end{array}$ & $\begin{array}{l}-0.036 \\
(-0.73)\end{array}$ & $\begin{array}{c}-0.381 \text { *** } \\
(-3.62)\end{array}$ & $\begin{array}{l}-0.010 \\
(-0.76)\end{array}$ & $\begin{array}{c}-0.623 * * * \\
(-11.35)\end{array}$ \\
\hline Large ISB Share & $\begin{array}{l}0.042 \\
(1.47)\end{array}$ & $\begin{array}{l}0.007 \\
(0.32)\end{array}$ & $\begin{array}{l}0.008 \\
(0.34)\end{array}$ & $\begin{array}{l}-0.017 \\
(-0.86)\end{array}$ & $\begin{array}{l}-0.017 \\
(-0.21)\end{array}$ & $\begin{array}{l}-0.043 \\
(-0.23)\end{array}$ & $\begin{array}{l}-0.425 \\
(-1.46)\end{array}$ & $\begin{array}{l}-0.006 \\
(-0.12)\end{array}$ & $\begin{array}{c}-0.531 * * \\
(-3.83)\end{array}$ \\
\hline Small ISW Share & $\begin{array}{l}0.000 \\
(0.01)\end{array}$ & $\begin{array}{l}0.009 \\
(0.68)\end{array}$ & $\begin{array}{l}0.031 \\
(1.12)\end{array}$ & $\begin{array}{l}0.014 \\
(0.93)\end{array}$ & $\begin{array}{c}0.050^{* * * *} \\
(4.88)\end{array}$ & $\begin{array}{l}-0.037 \\
(-0.89)\end{array}$ & $\begin{array}{c}-0.145^{* *} \\
(-3.03)\end{array}$ & $\begin{array}{l}-0.011 \\
(-1.14)\end{array}$ & $\begin{array}{c}-0.333 * * * \\
(-9.18)\end{array}$ \\
\hline Medium ISW Share & $\begin{array}{l}0.070 \\
(1.79)\end{array}$ & $\begin{array}{l}0.077 * \\
(2.01)\end{array}$ & $\begin{array}{l}0.013 \\
(0.18)\end{array}$ & $\begin{array}{l}0.028 \\
(1.20)\end{array}$ & $\begin{array}{l}-0.003 \\
(-0.23)\end{array}$ & $\begin{array}{c}0.116 * * * \\
(5.20)\end{array}$ & $\begin{array}{l}-0.049 \\
(-0.63)\end{array}$ & $\begin{array}{c}0.034 * * * \\
(5.39)\end{array}$ & $\begin{array}{c}-0.462 * * * \\
(-16.41)\end{array}$ \\
\hline Large ISW Share & $\begin{array}{c}0.196 * * * \\
(4.25)\end{array}$ & $\begin{array}{c}0.209 * * * \\
(4.05)\end{array}$ & $\begin{array}{l}0.131^{*} \\
(1.86)\end{array}$ & $\begin{array}{l}-0.016 \\
(-0.75)\end{array}$ & $\begin{array}{l}-0.053 \\
(-1.82)\end{array}$ & $\begin{array}{c}0.148 * * * \\
(5.16)\end{array}$ & $\begin{array}{l}0.196^{*} \\
(2.20)\end{array}$ & $\begin{array}{c}0.032 * * * * \\
(8.29)\end{array}$ & $\begin{array}{l}-0.183 \\
(-1.29)\end{array}$ \\
\hline Foreign Banks Share & $\begin{array}{l}-0.017 \\
(-0.27)\end{array}$ & $\begin{array}{l}-0.033 \\
(-0.40)\end{array}$ & $\begin{array}{l}-0.025 \\
(-0.26)\end{array}$ & $\begin{array}{l}-0.029 \\
(-0.93)\end{array}$ & $\begin{array}{l}-0.048 \\
(-0.37)\end{array}$ & $\begin{array}{l}0.214 \\
(0.67)\end{array}$ & $\begin{array}{l}0.785 \\
(1.47)\end{array}$ & $\begin{array}{l}0.046 \\
(0.54)\end{array}$ & $\begin{array}{c}-0.096 * * \\
(-2.59)\end{array}$ \\
\hline State Banks Share & $\begin{array}{l}-0.119 \\
(-1.23)\end{array}$ & $\begin{array}{l}-0.155 \\
(-1.31)\end{array}$ & $\begin{array}{l}-0.035 \\
(-0.32)\end{array}$ & $\begin{array}{c}-0.053^{*} \\
(-2.12)\end{array}$ & $\begin{array}{l}-0.017 \\
(-0.15)\end{array}$ & $\begin{array}{l}0.166 \\
(0.74)\end{array}$ & $\begin{array}{l}0.595 \\
(1.62)\end{array}$ & $\begin{array}{l}0.040 \\
(0.67)\end{array}$ & $\begin{array}{c}0.360^{* * * *} \\
(11.63)\end{array}$ \\
\hline Inflation & $\begin{array}{c}-0.165^{*} \\
(-2.17)\end{array}$ & $\begin{array}{c}-0.171^{*} \\
(-2.19)\end{array}$ & $\begin{array}{c}-0.220 * * \\
(-2.90)\end{array}$ & $\begin{array}{l}-0.034 \\
(-0.69)\end{array}$ & $\begin{array}{l}0.018 \\
(1.27)\end{array}$ & $\begin{array}{l}-0.016 \\
(-0.51)\end{array}$ & $\begin{array}{c}0.224 * \\
(2.18)\end{array}$ & $\begin{array}{l}-0.009 \\
(-0.89)\end{array}$ & $\begin{array}{c}0.199 * * * \\
(5.07)\end{array}$ \\
\hline Per Capita & $\begin{array}{l}0.347 \\
(1.18)\end{array}$ & $\begin{array}{l}0.399 \\
(1.35)\end{array}$ & $\begin{array}{l}0.230 \\
(0.66)\end{array}$ & $\begin{array}{c}0.415 * * * \\
(3.84)\end{array}$ & $\begin{array}{l}0.132 \\
(1.28)\end{array}$ & $\begin{array}{l}-0.418 \\
(-1.08)\end{array}$ & $\begin{array}{c}-4.992 * * * \\
(-6.44)\end{array}$ & $\begin{array}{l}-0.132 \\
(-1.51)\end{array}$ & $\begin{array}{c}-11.036 * * * \\
(-22.55)\end{array}$ \\
\hline Remittance Inflow & $\begin{array}{l}0.518 \\
(1.09)\end{array}$ & $\begin{array}{l}0.685 \\
(1.43)\end{array}$ & $\begin{array}{l}0.093 \\
(0.09)\end{array}$ & $\begin{array}{l}0.230^{*} \\
(1.91)\end{array}$ & $\begin{array}{c}0.423 * * \\
(2.60)\end{array}$ & $\begin{array}{l}0.441 \\
(0.60)\end{array}$ & $\begin{array}{l}0.130 \\
(0.12)\end{array}$ & $\begin{array}{l}0.084 \\
(0.42)\end{array}$ & $\begin{array}{c}-3.836 * * * \\
(-13.64)\end{array}$ \\
\hline Trend & $\begin{array}{c}0.931 * * \\
(2.73)\end{array}$ & $\begin{array}{l}0.852^{*} \\
(2.16)\end{array}$ & $\begin{array}{l}0.324 \\
(0.52)\end{array}$ & $\begin{array}{c}-0.182 * * \\
(-2.96)\end{array}$ & $\begin{array}{c}-0.508 * * * \\
(-3.88)\end{array}$ & $\begin{array}{l}0.044 \\
(0.19)\end{array}$ & $\begin{array}{c}2.157 * * * \\
(2.64)\end{array}$ & $\begin{array}{l}0.023 \\
(0.47)\end{array}$ & $\begin{array}{c}7.684 * * * \\
(13.82)\end{array}$ \\
\hline Constant & $\begin{array}{c}33.229 * * * \\
(5.95)\end{array}$ & $\begin{array}{l}35.501 * * * \\
(5.07)\end{array}$ & $\begin{array}{c}28.216^{*} \\
(1.93)\end{array}$ & $\begin{array}{l}0.634 \\
(0.22)\end{array}$ & $\begin{array}{c}39.175^{* * *} \\
(8.89)\end{array}$ & $\begin{array}{l}-2.601 \\
(-0.24)\end{array}$ & $\begin{array}{l}18.989 \\
(0.82)\end{array}$ & $\begin{array}{l}-0.411 \\
(-0.14)\end{array}$ & $\begin{array}{c}94.240 * * * \\
(23.99)\end{array}$ \\
\hline Observations & 104 & 100 & 106 & 119 & 28 & 28 & 27 & 28 & 22 \\
\hline R-squared & 0.557 & 0.516 & 0.382 & 0.161 & 0.854 & 0.833 & 0.871 & 0.833 & 0.963 \\
\hline Number of Country & 11 & 11 & 12 & 12 & 8 & 8 & 7 & 8 & 6 \\
\hline
\end{tabular}


Table 5.Cost-Inefficiency Analysis

This table presents the estimation of the Equation (2), using the ratio of total noninterest expense on total operating income (Inefficiency) as the proxy for inefficiency:

$$
\begin{aligned}
\text { Inefficiency }_{\mathrm{i}, \mathrm{t}}=\beta_{0}+ & \beta_{11} \times \text { Small_ISB_Share }_{\mathrm{j}, \mathrm{t}}+\beta_{12} \times \text { Medium_ISB_Share }_{\mathrm{j}, \mathrm{t}}+\beta_{13} \times \text { Large_ISB_Share }_{\mathrm{j}, \mathrm{t}}+ \\
& \beta_{21} \times \text { Small_ISW_Share }_{\mathrm{j}, \mathrm{t}}+\beta_{22} \times \text { Medium_ISW_Share }_{\mathrm{j}, \mathrm{t}}+\beta_{23} \times \text { Large_ISW_Share }_{\mathrm{j}, \mathrm{t}}+ \\
& \beta_{3} \times \mathrm{HHI}_{\mathrm{j}, \mathrm{t}}+\beta_{4} \times \text { Domestic_Interest_Rate }_{\mathrm{j}, \mathrm{t}}+\beta_{5} \times \text { Per_Capita }_{\mathrm{j}, \mathrm{t}}+\beta_{6} \times \text { Per_Capita_Growth }_{\mathrm{j}, \mathrm{t}}+ \\
& \beta_{7} \times \text { Capital }_{\mathrm{i}, \mathrm{t}}+\beta_{8} \times \text { Size }_{\mathrm{i}, \mathrm{t}}+\beta_{9} \times \text { Credit Risk }_{\mathrm{i}, \mathrm{t}}+\sum_{y=1}^{12} \beta_{10, \mathrm{y}} \times \text { Year_Dummies }_{\mathrm{t}, \mathrm{y}}+\xi_{\mathrm{j}, \mathrm{t}}
\end{aligned}
$$

We split our sample into two groups on the basis of the median proportion of Muslims in a country's population. Countries below the median value are classified in one group (called More Religiously Diverse Countries) and the rest are in the other group (called Predominantly Muslim Countries). The median value is 95\%. The results for More Religiously Diverse Countries are presented in columns (1) to (4), whereas columns (5) to (8) display our analysis for Predominantly Muslim Countries.

We regress Inefficiency on our variable of interest (i.e., Small ISB Share, Medium ISB Share and Large ISB Share)and control variables. In the first column we regress Inefficiency on Small ISB Share, Medium ISB Share and Large ISB Share while controlling for Small ISW Share, Medium ISW Share and Large ISW Share. In column (2), we include HHI, Domestic Interest Rate, Per Capita, and Per Capita Growth in our model. Column (3) illustrates the result when we add Capital, Sizeand Credit Risk to our model. In column (4) we add year dummies. Columns (5) to (8) depict the result when we use the Predominantly Muslim Countries subsample. Year dummies are included but not reported in the table.

\begin{tabular}{|c|c|c|c|c|c|c|c|c|}
\hline \multirow[b]{2}{*}{ Variables } & \multicolumn{4}{|c|}{ More Religiously Diverse Countries } & \multicolumn{4}{|c|}{ Predominantly Muslim Countries } \\
\hline & (1) & (2) & (3) & (4) & (5) & (6) & (7) & (8) \\
\hline Small ISB Share & $\begin{array}{c}-0.034 * * \\
(-2.00)\end{array}$ & $\begin{array}{c}-0.045^{* *} * \\
(-2.38)\end{array}$ & $\begin{array}{l}-0.035 \\
(-1.48)\end{array}$ & $\begin{array}{l}-0.037 \\
(-1.42)\end{array}$ & $\begin{array}{l}-0.000 \\
(-0.00)\end{array}$ & $\begin{array}{l}-0.010 \\
(-0.23)\end{array}$ & $\begin{array}{l}-0.007 \\
(-0.13)\end{array}$ & $\begin{array}{l}0.026 \\
(0.39)\end{array}$ \\
\hline Medium ISB Share & $\begin{array}{l}-0.004 \\
(-0.14)\end{array}$ & $\begin{array}{l}-0.025 \\
(-0.87)\end{array}$ & $\begin{array}{l}-0.032 \\
(-0.91)\end{array}$ & $\begin{array}{l}-0.035 \\
(-0.94)\end{array}$ & $\begin{array}{c}-0.110 * * \\
(-2.27)\end{array}$ & $\begin{array}{c}-0.093^{*} \\
(-1.68)\end{array}$ & $\begin{array}{c}-0.101^{*} \\
(-1.81)\end{array}$ & $\begin{array}{l}0.012 \\
(0.17)\end{array}$ \\
\hline Large ISB Share & $\begin{array}{c}-0.068^{*} \\
(-1.73)\end{array}$ & $\begin{array}{l}-0.054 \\
(-0.95)\end{array}$ & $\begin{array}{l}-0.008 \\
(-0.11)\end{array}$ & $\begin{array}{l}0.029 \\
(0.41)\end{array}$ & $\begin{array}{c}-0.125^{*} \\
(-1.85)\end{array}$ & $\begin{array}{l}-0.083 \\
(-1.16)\end{array}$ & $\begin{array}{c}-0.334 * * \\
(-2.23)\end{array}$ & $\begin{array}{c}-0.367 * * \\
(-2.40)\end{array}$ \\
\hline Small ISW Share & $\begin{array}{l}0.040 \\
(1.43)\end{array}$ & $\begin{array}{l}0.023 \\
(0.84)\end{array}$ & $\begin{array}{l}0.014 \\
(0.26)\end{array}$ & $\begin{array}{l}-0.001 \\
(-0.02)\end{array}$ & $\begin{array}{l}0.049 \\
(0.45)\end{array}$ & $\begin{array}{l}0.034 \\
(0.32)\end{array}$ & $\begin{array}{l}-0.074 \\
(-0.50)\end{array}$ & $\begin{array}{l}-0.089 \\
(-0.60)\end{array}$ \\
\hline Medium ISW Share & $\begin{array}{l}-0.036 \\
(-0.85)\end{array}$ & $\begin{array}{c}-0.101 * * \\
(-2.10)\end{array}$ & $\begin{array}{c}-0.161 * * \\
(-2.54)\end{array}$ & $\begin{array}{c}-0.145^{* *} \\
(-2.21)\end{array}$ & $\begin{array}{l}0.168 \\
(1.54)\end{array}$ & $\begin{array}{l}0.181 \\
(1.45)\end{array}$ & $\begin{array}{l}-0.031 \\
(-0.17)\end{array}$ & $\begin{array}{l}-0.172 \\
(-0.85)\end{array}$ \\
\hline Large ISW Share & $\begin{array}{l}-0.057 \\
(-1.09)\end{array}$ & $\begin{array}{c}-0.137 * * * \\
(-2.67)\end{array}$ & $\begin{array}{c}-0.168 * * * \\
(-2.87)\end{array}$ & $\begin{array}{c}-0.137 * * \\
(-2.15)\end{array}$ & $\begin{array}{l}0.125 \\
(0.41)\end{array}$ & $\begin{array}{l}0.157 \\
(0.50)\end{array}$ & $\begin{array}{l}-0.090 \\
(-0.65)\end{array}$ & $\begin{array}{l}-0.001 \\
(-0.01)\end{array}$ \\
\hline HHI & & $\begin{array}{l}-0.030 \\
(-0.37)\end{array}$ & $\begin{array}{l}-0.059 \\
(-0.51)\end{array}$ & $\begin{array}{l}-0.047 \\
(-0.38)\end{array}$ & & $\begin{array}{l}-0.212 \\
(-1.09)\end{array}$ & $\begin{array}{l}0.303 \\
(1.64)\end{array}$ & $\begin{array}{l}0.287 \\
(1.24)\end{array}$ \\
\hline Domestic Interest Rate & & $\begin{array}{l}0.126 \\
(0.55)\end{array}$ & $\begin{array}{l}0.287 \\
(0.97)\end{array}$ & $\begin{array}{l}0.083 \\
(0.17)\end{array}$ & & $\begin{array}{c}0.444 * * * \\
(3.13)\end{array}$ & $\begin{array}{c}0.472 * * * \\
(2.76)\end{array}$ & $\begin{array}{l}0.333 \\
(1.63)\end{array}$ \\
\hline Per Capita & & $\begin{array}{c}-0.162 * * * \\
(-3.32)\end{array}$ & $\begin{array}{c}-0.139 * * \\
(-2.38)\end{array}$ & $\begin{array}{c}-0.121 * \\
(-1.78)\end{array}$ & & $\begin{array}{l}-0.386 \\
(-0.78)\end{array}$ & $\begin{array}{l}0.880^{*} \\
(1.68)\end{array}$ & $\begin{array}{l}0.635 \\
(0.36)\end{array}$ \\
\hline Per Capita Growth & & $\begin{array}{c}-0.219^{*} \\
(-1.68)\end{array}$ & $\begin{array}{l}-0.146 \\
(-1.12)\end{array}$ & $\begin{array}{l}-0.149 \\
(-0.99)\end{array}$ & & $\begin{array}{l}0.173 \\
(0.61)\end{array}$ & $\begin{array}{l}0.232 \\
(0.64)\end{array}$ & $\begin{array}{l}0.034 \\
(0.09)\end{array}$ \\
\hline Capital & & & $\begin{array}{l}-0.053 \\
(-0.38)\end{array}$ & $\begin{array}{l}-0.026 \\
(-0.17)\end{array}$ & & & $\begin{array}{c}-0.259^{*} \\
(-1.92)\end{array}$ & $\begin{array}{l}-0.172 \\
(-1.24)\end{array}$ \\
\hline Size & & & $\begin{array}{l}-0.719 \\
(-0.82)\end{array}$ & $\begin{array}{l}-0.323 \\
(-0.35)\end{array}$ & & & $\begin{array}{l}-1.267 \\
(-0.75)\end{array}$ & $\begin{array}{l}-0.434 \\
(-0.27)\end{array}$ \\
\hline Credit Risk & & & $\begin{array}{l}0.129 \\
(1.31)\end{array}$ & $\begin{array}{l}0.130 \\
(1.32)\end{array}$ & & & $\begin{array}{c}0.492 * * * \\
(3.18)\end{array}$ & $\begin{array}{c}0.384 * * \\
(2.59)\end{array}$ \\
\hline Constant & $\begin{array}{c}56.8 \text { *** } \\
(46.45)\end{array}$ & $\begin{array}{l}61.1 * * * \\
(21.01)\end{array}$ & $\begin{array}{c}69.6^{* * * *} \\
(5.24)\end{array}$ & $\begin{array}{c}66.3^{* * * *} \\
(4.65)\end{array}$ & $\begin{array}{c}61.3 * * * * \\
(23.28)\end{array}$ & $\begin{array}{c}62.0^{* * * *} \\
(9.73)\end{array}$ & $\begin{array}{l}59.3^{*} \\
(1.97)\end{array}$ & $\begin{array}{c}51.7 \\
(1.13)\end{array}$ \\
\hline Year Dummies & No & No & No & Yes & No & No & No & Yes \\
\hline Observations & 1,714 & 1,677 & 1,179 & 1,179 & 901 & 855 & 506 & 506 \\
\hline R-squared & 0.007 & 0.014 & 0.030 & 0.041 & 0.019 & 0.074 & 0.187 & 0.246 \\
\hline Number of Banks & 248 & 247 & 219 & 219 & 145 & 135 & 100 & 100 \\
\hline
\end{tabular}

We apply the fixed-effect technique for our estimation. Standard errors are clustered at the country level. Robust z-statistics are reported in parentheses. $* * *, * *$, and $*$ indicate significance at $1 \%, 5 \%$, and $10 \%$ respectively. See table A1 for variable definitions. 